\title{
ARTICLE
}

\section{Electronic Effects in Mixed N-Heterocyclic Carbene/Phosphite Indenylidene Ruthenium Metathesis Catalysts}

Received 00th January 20xx, Accepted 00th January 20xx DOI: $10.1039 / \times 0 \times x 00000 x$
Yannick D. Bidal, ${ }^{a}$ César A. Urbina-Blanco, ${ }^{\mathrm{a}, \mathrm{b}}$ Albert Poater, ${ }^{\mathrm{c}}$ David B. Cordes, ${ }^{\mathrm{a}}$ Alexandra M. Z.

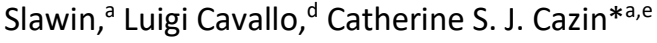

Five new complexes $\left[\mathrm{RuCl}_{2}\right.$ (SIMes)(Ind)(O-pXC $\left.\left.\mathrm{H}_{4}\right)\right]$ bearing different para-substituted triphenylphosphites $\left(\mathrm{X}=\mathrm{H}, \mathrm{OCH}_{3}\right.$, $\mathrm{CF}_{3}, \mathrm{Cl}_{1} \mathrm{SF}_{5}$ and $\mathrm{CN}$ ) were synthesised and used to study the effect of the electronic properties of the phosphite on olefin metathesis activity. Investigations of the physical properties of the new ligands and complexes were performed using physicochemical and DFT calculations. The catalytic activity of the complexes was benchmarked in challenging ring closing metathesis transformations featuring the formation of tetra-substituted double bonds. Complex [RuCl $2\left(\mathrm{SIMes}_{\text {(Ind) }} \mathrm{P}(\mathrm{O}\right.$ $\left.\left.p \mathrm{CF}_{3} \mathrm{C}_{5} \mathrm{H}_{4}\right)_{3}\right](3 \mathrm{c})$ exhibited a particularly high catalytic activity, superior to state-of-the-art catalysts, and was further tested on a wide range of substrates.

\section{Introduction}

In recent decades, olefin metathesis has become a powerful tool widely used in organic chemistry, ${ }^{1}$ total synthesis ${ }^{2}$ and in the synthesis of macromolecules. ${ }^{3}$ Ruthenium-based complexes for such transformations appear to be more stable towards air and moisture, ${ }^{4}$ more functional group tolerant and react preferentially with carbon-carbon double bonds over other functionalities (such as carbonyl derivatives) compared to other systems. ${ }^{5}$ For these reasons, such complexes have been broadly studied since the 1990s. ${ }^{6}$ Thus, various classes of ruthenium complexes of general formula $\mathrm{RuX}_{2} \mathrm{~L}_{2} \mathrm{CHR}$ have been successively synthesised since the major breakthrough reported by Grubbs who developed the $1^{\text {st }}$ generation catalyst Gru-I (Figure 1). ${ }^{7} \mathrm{~N}$-Heterocyclic carbenes (NHCs) were then used as ancillary ligands to replace one phosphine to produce the $2^{\text {nd }}$ generation alkylidene ruthenium pre-catalysts Gru-II (Figure 1). ${ }^{8}$ Modification of the benzylidene moiety into 1isopropoxy-vinylbenzene afforded chelated complexes, best known as Hoveyda catalysts Hov-II (Figure 1). ${ }^{9}$ The benzylidene moiety was replaced subsequently by an indenylidene fragment giving rise to complexes such as Ind-II (Figure 1) which proved to be more thermally stable. ${ }^{10}$ One of the latest

\footnotetext{
a. EaStCHEM School of Chemistry, University of St Andrews, St Andrews, KY16 9ST UK.

b. Laboratory for Chemical Technology, Ghent University, Technologiepark 125, B9052 Gent, Belgium

c. Institut de Química Computacional i Catàlisi, Departament de Química, University of Girona, Girona 17003, Catalonia, Spain.

d. KAUST Catalysis Center, Physical Sciences and Engineering Division, King Abdullah University of Science and Technology, Thuwal, 23955-6900, Saudi Arabia. e. Centre for Sustainable Chemistry, Department of Chemistry, Ghent University, Krijgslaan 281 -53, 9000 Gent, Belgium.E-mail: Catherine.Cazin@UGent.be Electronic Supplementary Information (ESI) available: [procedures for synthesis, catalysis, calorimetry, crystallographic data, NMR spectra and calculation for $\% V_{B u r}$ and 3D mapping]. See DOI: 10.1039/x0xx00000x
}

advances in indenylidene-containing ruthenium complexes was the replacement of the phosphine ligand by a pyridine adduct. ${ }^{11}$ Nolan and co-workers published a facile synthesis of Ind-III which exhibits improved stability and better initiation rates than their benzylidene analogues, despite poor activity with respect to difficult substrates due to rapid decomposition of the active species. ${ }^{11 a, e}$ Mixed $\mathrm{NHC} /$ phosphine rutheniumbased complexes are of significant interest as these provide opportunities to further improve both catalyst stability and reactivity. ${ }^{12}$
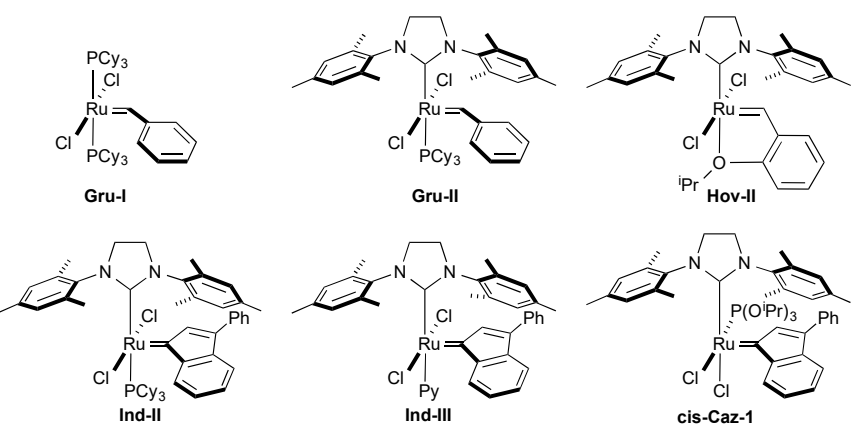

Fig. 1 Various generations of alkylidene ruthenium-based catalysts for olefin metathesis.

If phosphines can be considered privileged ligands, other phosphorus-based ligands have however been much less studied in ruthenium-based complexes. This is surprising as a number of phosphite ligands have shown interesting catalystmodifier properties when employed with other metals in various other reactions. ${ }^{13}$ Among such systems, for example, phosphites have shown excellent results in Suzuki-Miyaura cross-coupling palladium-catalysed reactions. ${ }^{14}$ Investigations carried out with this strong $\pi$-acidic ligand showed synergism between phosphites and other strong $\sigma$-donor ligands such as 
phosphines or NHCs and led to improved pre-catalyst lifetime. ${ }^{14,15}$

In light of such reports, our group initiated investigations on phosphite-containing ruthenium pre-catalysts for olefin metathesis. ${ }^{16}$ We reported the first examples of mixed $\mathrm{NHC} /$ phosphite ruthenium-based complexes bearing an indenylidene cis-Caz-1 (Figure 1). To the best of our knowledge, cis-Caz-1 was the first ruthenium complex with a square-pyramidal geometry featuring a phosphite ligand exhibiting a cis configuration to the NHC. The already known synergistic effect between strong $\pi$-acidic phosphite and strong $\sigma$-donor NHC has also been observed in this case. ${ }^{16}$ cisCaz-1 proved to have a longer lifetime and exhibited improved catalytic activity compared to its phosphine analogues. ${ }^{16 a, c}$ This complex is also more thermally stable than its relatives, making it one of the state-of-the-art ruthenium-based olefin metathesis pre-catalysts for the ring closing metathesis of challenging substrates at low catalyst loadings. ${ }^{16 c}$ In order to obtain a better understanding of the role played by the phosphite, we carried out investigations on the steric effect of the throwaway ligand. Therefore, to assess the effect of their steric properties, various trialkylphosphites as well as triarylphosphites were employed to extend the number of mixed NHC-phosphite indenylidene ruthenium complexes. Physical properties of the complexes bearing a phosphite are altered compared to their phosphine analogues, especially considering the lower basicity of these ligands. As a result, $\mathrm{P}(\mathrm{OR})_{3}$ ligands seem to bind more strongly to the ruthenium via $\pi^{*}$ back-donation from the metal. A general trend was uncovered between reactivity and phosphite substitution, showing bulkier $\mathrm{P}(\mathrm{OR})_{3}$ ligand containing pre-catalysts exhibited higher catalytic efficiency. This reactivity trend could be correlated with the affinity of the different phosphites for the metal centre. Further investigation using solution calorimetry showed the relative Ru-P bond dissociation energy $(B D E)$ is mainly dependent on the electronic parameter of the ligand. ${ }^{16 c}$

Since steric and electronic properties are both important parameters in dictating catalyst activity, after studying the steric properties of phosphites, it became necessary to gain a better understanding of the role played by the electronic properties. Especially since electronic modifications of the phosphine on indenylidene-containing ruthenium complexes by the introduction of para-substituents dramatically altered catalytic activities of similar systems. ${ }^{17}$ Triphenylphosphites were selected to probe ligand electronic effects as they can be easily electronically tuned without changing steric bulk (triphenylphosphite and tri-para-tolyl-phosphite have the same cone angle $\theta$ ). ${ }^{18}$ Herein we report on the influence of electronic properties on the behaviour and catalytic properties of indenylidene mixed $\mathrm{NHC} /$ phosphite olefin metathesis catalysts.

\section{Results and Discussion}

A selection of substituents ranging from electron-donating to electron-withdrawing at the para position of the triphenylphosphite was established as a way to assess the influence of electronic properties on the pre-catalyst. These functional groups are tolerant to ruthenium and electronically described by the Hammett parameter (or Hammett sigma constant). ${ }^{19}$ These ligands were synthesised according to procedures described in the literature. ${ }^{19 b, 20}$ Phosphorus trichloride and para-substituted phenols react in the presence of triethylamine to afford the desired ligands $\mathbf{1 b}$-f (Scheme $\mathbf{1}$ ). All phosphite ligands were obtained straightforwardly with ${ }^{1} \mathrm{H}$ and ${ }^{31} \mathrm{P}-\left\{{ }^{1} \mathrm{H}\right\}$ NMR data matching those reported in the literature. ${ }^{19 b, 20}$

$$
\begin{aligned}
& \mathrm{PCl}_{3}+3 \mathrm{R}-\mathrm{OH} \underset{\mathrm{Et}_{2} \mathrm{O}, 24 \mathrm{~h}, \mathrm{rt}}{\stackrel{\mathrm{Et}_{2} \mathrm{~N}(3.5 \mathrm{eq})}{\longrightarrow}} \mathrm{P}+\mathrm{O} \\
& \text { 1b } \mathrm{R}=\mathrm{OMe} \\
& \text { 1c } \mathrm{R}=\mathrm{CF}_{3} \\
& \text { 1e } \mathrm{R}=\mathrm{SF}_{5} \\
& \begin{array}{l}
\text { 1e } R=S F_{5} \\
\text { if } R=C N
\end{array}
\end{aligned}
$$

Scheme 1. Synthetic access to para-substituted phenyl phosphites.

Calorimetric studies were undertaken to determine enthalpies of reactions involving these phosphites with $p$-cymene ruthenium dichloride dimer (Table 1 ) as a model ruthenium system. The dissociation of the ancillary phosphorus ligand is a key step in the olefin metathesis catalytic cycle; therefore, further information on the bonding behaviour of phosphite to ruthenium is of great interest. ${ }^{21}\left[\mathrm{Ru}(\mu-\mathrm{Cl}) \mathrm{Cl}\left(\eta^{6} \text {-cymene }\right)\right]_{2}(\mathbf{A})$ is particularly suitable for such experiments as it reacts rapidly, and quantitatively with most ligands without formation of any side-product. ${ }^{22}$

Table 1. Calorimetric data obtained by the scission of $\left[\mathrm{Ru}(\mu-\mathrm{Cl}) \mathrm{Cl}\left(\eta^{6}-\mathrm{cymene}\right)\right]_{2}$ with phosphites (L).

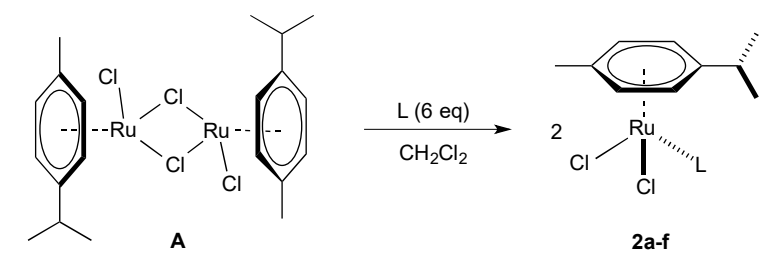

\begin{tabular}{ccccc} 
Entry & Ligand $(\mathrm{L})$ & Complex & $\begin{array}{c}-\Delta \mathrm{H}_{\mathrm{rxn}} \\
\left(\mathrm{kcal} \cdot \mathrm{mol}^{-1}\right)\end{array}$ & $\begin{array}{c}\text { Rel. BDE } \\
(\mathrm{kcal} \cdot \mathrm{mol}-1\end{array}$ \\
\hline 1 & $\mathrm{P}\left(\mathrm{O}-p-\mathrm{SF}_{5} \mathrm{C}_{6} \mathrm{H}_{4}\right)_{3}$ & $\mathbf{2 e}$ & $30.2 \pm 0.2$ & 15.1 \\
2 & $\mathrm{P}\left(\mathrm{O}-p-\mathrm{CNC}_{6} \mathrm{H}_{4}\right)_{3}$ & $\mathbf{2 f}$ & $30.6 \pm 0.6$ & 15.2 \\
3 & $\mathrm{P}\left(\mathrm{O}-p-\mathrm{CF}_{3} \mathrm{C}_{6} \mathrm{H}_{4}\right)_{3}$ & $\mathbf{2 c}$ & $31.5 \pm 0.4$ & 15.8 \\
4 & $\mathrm{P}\left(\mathrm{O}-p-\mathrm{ClC}_{6} \mathrm{H}_{4}\right)_{3}$ & $\mathbf{2 d}$ & $33.3 \pm 0.3$ & 16.6 \\
5 & $\mathrm{P}\left(\mathrm{OC}_{6} \mathrm{H}_{5}\right)_{3}$ & $\mathbf{2 a}$ & $34.1 \pm 0.4$ & 17.0 \\
6 & $\mathrm{P}\left(\mathrm{O}-p-\mathrm{OCH}_{3} \mathrm{C}_{6} \mathrm{H}_{4}\right)_{3}$ & $\mathbf{2 b}$ & $35.0 \pm 0.5$ & 17.5
\end{tabular}

The suitability of such system relies on the cleavage of only weak $\mathrm{Ru}-\mathrm{Cl}$ bonds and the formation of two new Ru-L ( $\mathrm{L}=$ ligand) bonds during the reaction. The formation of the ruthenium $p$-cymene phosphite monomer is exothermic, enthalpies of reaction were measured and relative bond dissociation energies (BDE) were calculated. A general trend 
was found within this series of para-substituted phenylphosphites, and as expected, phosphites bearing electron-donating substituents have higher bond dissociation energies than those bearing electron-withdrawing substituents (Table 1). According to these results, amongst all ligands examined, $\mathrm{P}\left(\mathrm{O}-p-\mathrm{SF}_{5} \mathrm{C}_{6} \mathrm{H}_{4}\right)_{3}$ should be the most prone to dissociate from the ruthenium metal centre (BDE Ru-P(O- $p$ $\left.\left.\mathrm{SF}_{5} \mathrm{C}_{6} \mathrm{H}_{4}\right)_{3}=15.1 \mathrm{kcal} \cdot \mathrm{mol}^{-1}\right)($ Table 1 , entry 1$)$, providing that the model based on $\mathbf{A}$ is transferable to the Ru-based olefin metathesis systems. The later were obtained from a straightforward method, consisting of displacing a pyridine fragment by a phosphite ligand (Table 2).

Table 2. Synthesis of para-substituted triphenylphosphite-containing ruthenium pre-catalysts.

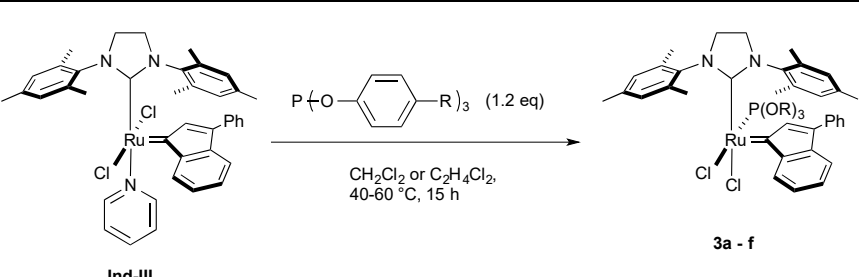

\begin{tabular}{ccccc}
\hline Complex & $\mathrm{P}(\mathrm{OR})_{3}$ & Yield (\%) & $\sigma_{\mathrm{p}}{ }^{19 a}$ & $\%$ Bur $^{23,24}$ \\
\hline 3a ${ }^{16 c}$ & $\mathrm{P}\left(\mathrm{OC}_{6} \mathrm{H}_{5}\right)_{3}$ & 76 & 0 & 25.4 \\
3b & $\mathrm{P}\left(\mathrm{O}-p-\mathrm{OCH}_{3} \mathrm{C}_{6} \mathrm{H}_{4}\right)_{3}$ & 67 & -0.27 & 27.6 \\
3c & $\mathrm{P}\left(\mathrm{O}-p-\mathrm{CF}_{3} \mathrm{C}_{6} \mathrm{H}_{4}\right)_{3}$ & 61 & 0.53 & 26.9 \\
3d & $\mathrm{P}\left(\mathrm{O}-p-\mathrm{ClC}_{6} \mathrm{H}_{4}\right)_{3}$ & 66 & 0.23 & 27.0 \\
3e & $\mathrm{P}\left(\mathrm{O}-p-\mathrm{SF}_{5} \mathrm{C}_{6} \mathrm{H}_{4}\right)_{3}$ & 53 & 0.68 & 24.8 \\
3f & $\mathrm{P}\left(\mathrm{O}-p-\mathrm{CNC}_{6} \mathrm{H}_{4}\right)_{3}$ & 90 & 0.66 & 27.7 \\
\hline
\end{tabular}

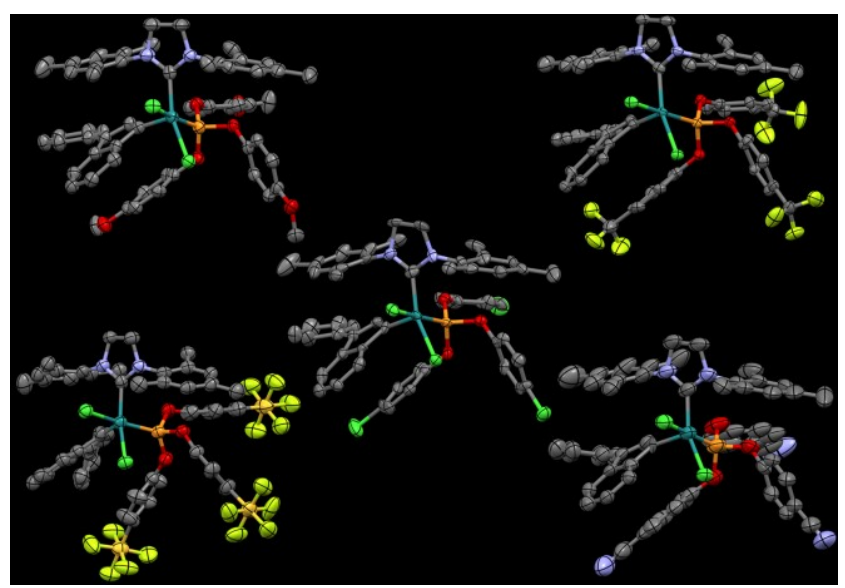

Fig. 2 Molecular representations of complexes $\mathbf{3 b}$-f ( $50 \%$ thermal ellipsoids). Hydrogen atoms and minor components of disorder are omitted for clarity. ${ }^{23}$

Pre-catalysts 3a-f were obtained in microanalytically pure form in good to excellent yields. NMR studies showed that all complexes exhibit a cis-dichloro arrangement, a rare configuration also observed in related mixed $\mathrm{NHC} /$ phosphite ruthenium-based complexes. ${ }^{16}$ These cis isomers are easily distinguished from the trans analogues due to typical shifts in ${ }^{1} \mathrm{H}$ and ${ }^{13} \mathrm{C}-\left\{{ }^{1} \mathrm{H}\right\}$ NMR spectroscopy (doublet at $\delta_{\mathrm{H}} \mathrm{ca} .8 .6 \mathrm{ppm}$ and $\delta_{c} c a .292 .0 \mathrm{ppm}$ with ${ }^{2} J_{\mathrm{CP}}=25 \mathrm{~Hz}$ ). The structures and geometries of complexes 3b-f were unambiguously confirmed by X-ray diffraction on single crystals (Figure 2).

Complexes 3a-f adopt a slightly distorted square pyramidal geometry with the indenylidene at the apex of the pyramid. Such configurations have already been observed with similar systems and appear to be characteristic of mixed SIMes/phosphite indenylidene ruthenium complexes. ${ }^{16 a, c}$ Moreover, the structural data for 3a-f support the earlier hypothesis that modifying the substituent in para position does not significantly modify the steric properties of the ligand. This has been quantitatively confirmed by calculating the percent buried volumes (\% $V_{\text {Bur }}$ ) for NHCs (see ESI) and phosphites in each complex (Table 2). ${ }^{24}$ In all cases, only slight variations of both $\% V_{\text {Bur }}$ were observed (average value of 26.5 \pm 1.7 for $\mathrm{P}(\mathrm{OR})_{3}$ and $30.8 \pm 0.4$ for SIMes) meaning that the phosphites have very similar steric properties and do not affect the SIMes moiety sterically. ${ }^{25,26}$

Analysis of the relevant Ru-bond distances indicates that increasing the electronic donor ability of para-substituents on the phosphite results in some variation of the Ru-indenylidene, Ru-SIMes and Ru-phosphite distances (Table 3). Although no clear trend can be observed based solely on the experimental bond-distances, examination of the DFT calculated structures shows that longer Ru-P distances are found for more electrondonating para-substituents, which is somewhat counterintuitive considering that electron-donating para-substituents increase the relative BDE (Table 1). It should be stated that enthalpy data represent the overall changes in bonds within the molecule, and cannot be attributed to changes in one single bond within the complex. Bond reorganisation is a term included within the experimental enthalpy value. The idea that electron-donating para-substituents increase the $\sigma$-donation of the phosphite while decreasing their $\pi$-acidity is a plausible explanation to this observed trend. This is confirmed by analysis of the energy of the HOMO and LUMO of the free $\mathrm{P}(\mathrm{O}$ $\left.p-\mathrm{OCH}_{3} \mathrm{C}_{6} \mathrm{H}_{4}\right)_{3}$ and $\mathrm{P}\left(\mathrm{O}-p-\mathrm{SF}_{5} \mathrm{C}_{6} \mathrm{H}_{4}\right)_{3}$ ligands, which are shifted $0.64 \mathrm{eV}$ higher in energy relative to the HOMO and LUMO of $\mathrm{P}\left(\mathrm{O}-\mathrm{p}-\mathrm{SF}_{5} \mathrm{C}_{6} \mathrm{H}_{4}\right)_{3}$. The electron-donor para-substituents increase the HOMO of the free phosphite, increasing their bonding ability (larger BDE). However, they also increase the energy of the LUMO, reducing their back-bonding ability (longer Ru-P bond). Support for this hypothesis comes from the slightly longer average $\mathrm{P}-\mathrm{O}$ bond in $3 \mathrm{e}, 1.679(9) \AA$, than in 3b, 1.672(14) $\AA$, which suggests slightly stronger back-donation in $3 e$ despite the rather low differences in bond distances and broad standard deviations, especially for P-O bond distances (see Table S1).

Modifying the electronic environment of the metal centre by changing the para-substituent on the phosphite ligand affects the bonding to ruthenium. Surprisingly, the Ru-P bond distance decreases with more electron-withdrawing functional groups. This was observed in $\mathbf{3 c}$ where the Ru-P bond is expected to be weaker compared to that found in $\mathbf{3 a}$ or $\mathbf{3 b}$ (Table 3 ), but DFT calculations showed the strengthening $\pi$-backdonation as the origin of such singularities. Bond lengths from the crystallographic study and DFT calculations both correlated with calorimetric experiments supporting that the dissociation 
of phosphorus ligands with strong electron-withdrawing substituents such as $\mathbf{3} \mathbf{c}$ and $\mathbf{3 e}$ should be easier. Therefore the electronic properties of phosphites are associated with the ease of generating the active species in olefin metathesis by dissociation of the ancillary ligand.

Table 3. Selected measured ${ }^{23}$ and calculated bond distances $(\AA)$ for complexes 3a-f.

\begin{tabular}{ccccccc}
\hline Complex & 3a16c & 3b & 3c & 3d & 3e & 3f \\
\hline Ru-Ind & & & & & & \\
Measured & $1.866(4)$ & $1.881(4)$ & $1.856(4)$ & $1.891(13)$ & $1.888(6)$ & $1.998(16)$ \\
Calculated & 1.903 & 1.901 & 1.904 & 1.904 & 1.905 & 1.906 \\
\hline Ru-NHC & & & & & & \\
Measured & $2.080(4)$ & $2.068(5)$ & $2.062(5)$ & $2.068(15)$ & $2.083(6)$ & $2.060(6)$ \\
Calculated & 2.068 & 2.066 & 2.067 & 2.068 & 2.070 & 2.069 \\
\hline Ru-P & & & & & & \\
Measured & $2.218(12)$ & $2.2206(14)$ & $2.2229(13)$ & $2.232(4)$ & $2.2083(19)$ & $2.222(2)$ \\
Calculated & & & 2.231 & & & \\
\hline
\end{tabular}

Kinetic profiling of complexes 3a-f was performed to compare their catalytic activities. These experiments were carried out on ring closing metathesis (RCM) of challenging substrate $\mathbf{4}$ at relatively low catalyst loading (Figure 3 ). The reactivity trend of complexes 3a-e for the ring closing metathesis of substrate 4 can be correlated with the Ru-P bond lengths and relative BDEs. As expected, the catalytic activity depends on the electronic properties of the phosphite ligand. The reaction rates increase on going from electron-donating to strong electron-withdrawing substituents on the phosphite ligand. For $\mathbf{3 c}$ and $\mathbf{3 e}$ the reaction reached completion in one hour, whereas it needed more than two hours for $\mathbf{3 a}$ and $\mathbf{3 b}$ (Figure 3). Interestingly, $\mathbf{3 f}$ falls outside the trend displaying a very slow reaction rate, a behaviour that has also been observed when RCM of a more challenging substrate was performed. The lower reactivity is attributed to the reversible coordination ability of the nitrile group to the ruthenium centre slowing the overall kinetics of the metathesis reaction. This hypothesis was confirmed by an experiment where 1 equivalent of benzonitrile $(0.5 \mathrm{mmol})$ was added to the reaction mixture containing $3 e$ (Figure 3 ). In the RCM of challenging tetrasubstituted substrate $\mathbf{6}$, all catalysts exhibited excellent activities with the notable exception of $\mathbf{3 f}$ (Table 4).

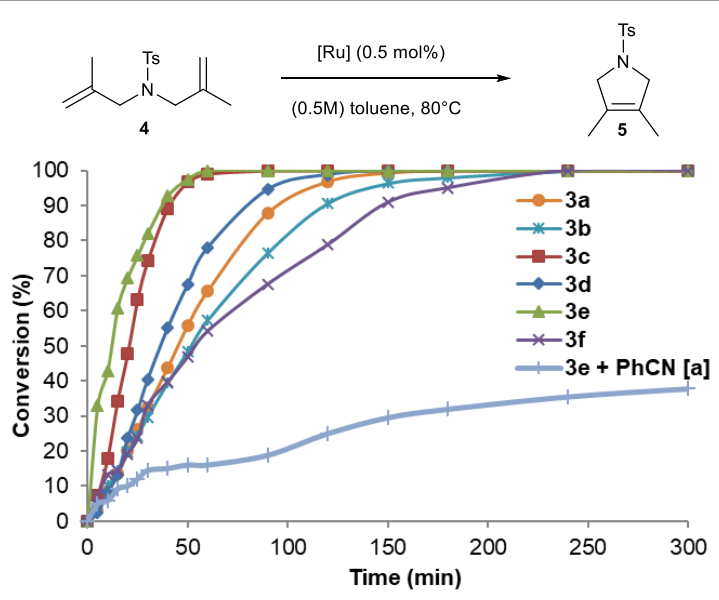

Fig. 3 Reaction conditions: substrate $(0.5 \mathrm{mmol})$, pre-catalyst $(0.5 \mathrm{~mol} \%)$, toluene $(0.5 \mathrm{M}), 80^{\circ} \mathrm{C}$. Average of 2 reactions; conversion determined by GC.
Table 4. Comparison of complexes 3a-f in RCM of challenging substrate 6 . $^{\text {a }}$

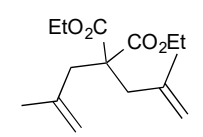

6

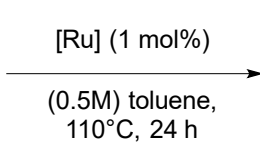

$110^{\circ} \mathrm{C}, 24 \mathrm{~h}$

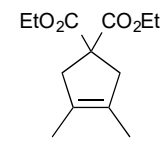

7

\begin{tabular}{ccccccc}
\hline Complex & 3a & 3b & 3c & 3d & 3e & 3f \\
\hline Conv (\%) & 82 & 80 & 92 & 84 & 87 & 43 \\
\hline
\end{tabular}

a Reaction conditions: substrate $(0.25 \mathrm{mmol})$, pre-catalyst (1 mol\%), toluene $(0.5 \mathrm{M}), 110^{\circ} \mathrm{C}, 24 \mathrm{~h}$. Average of 2 reactions; conversion determined by GC.

DFT calculations were performed to rationalise the impact of the para-substituents on the catalytic activity. Considering that the distal para-substituents can hardly impact the steric features of $\mathbf{3 a - f}$, their electronic properties were investigated. Specifically, the hardness $(\eta)$, and the electrophilicity $(\omega)$ of 3a-f were calculated. The hardness is related to the HOMOLUMO gap, and no meaningful variation was found in the $\eta$ of 3a-f, which is calculated to be practically equal to $0.56 \mathrm{eV}$ for all complexes (see ESI for details). The different parasubstituents shift the HOMO and LUMO of the free phosphite by roughly the same amount, and thus the HOMO-LUMO gap in the complex is hardly affected. Contrarily, the electrophilicity is directly related to the energy of the HOMO and LUMO, and thus different para-substituents have an impact on this property. Indeed, the electrophilicity of 3a-f strictly correlates with the electronic properties of the parasubstituent, as measured by the $\sigma_{\mathrm{p}}$ Hammett constant (Figure 4); complexes bearing an electron withdrawing parasubstituent have a higher electrophilicity. On the other hand, the relative BDEs also correlate almost perfectly with $\sigma_{p}$, which indicates an almost perfect correlation, $R^{2}=0.97$, between the BDEs and $\omega$ (Table 1). This allows to correlate an experimental behaviour to a calculated property.

Considering that electron withdrawing para-substituents lead to better catalytic activity, calculations suggest that the key to good catalytic performance is the electrophilicity of the complex, which can be related to the affinity of the complex for the substrate. Seeing that there is a growing body of evidence that the activation of Ru-complexes for olefin metathesis follow an associative interchange mechanism, ${ }^{27}$ it is tempting to suggest that a more electrophilic complex is more prone to undergo such a mechanism.

Catalytic transformations were further explored with the most efficient catalyst. Despite slightly better catalytic activity as gauged by kinetic profiling, 3e was not selected for further catalytic investigations as its synthesis costs six times more than the preparation of $\mathbf{3 c}$ which also gave excellent results. A temperature profile was first performed to find the best conditions for RCM (Table 5). 


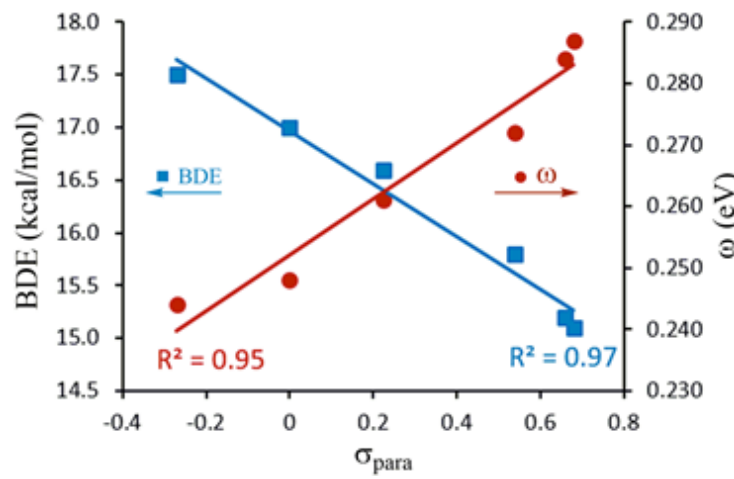

Fig. 4 Plot of the relative BDE of the phosphite in complexes 3a-f and of electrophilicity $\omega$ of complexes 3a-f versus the $\sigma_{\mathrm{p}}$ Hammett constant.

Table 5. Temperature profile of complex $3 \mathrm{c}$ on challenging RCM. ${ }^{\mathrm{a}}$

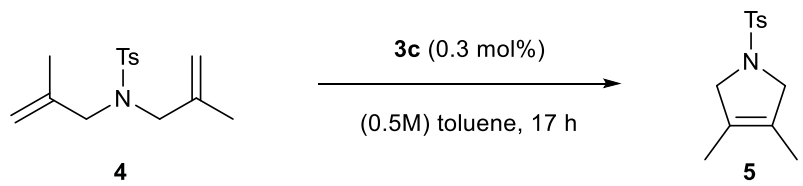

\begin{tabular}{ccccccccc}
\hline $\mathrm{T}\left({ }^{\circ} \mathrm{C}\right)$ & 30 & 40 & 50 & 60 & 70 & 80 & 90 & 110 \\
\hline Conv $(\%)$ & 6 & 10 & 22 & 36 & 62 & 93 & 94 & 99 \\
\hline
\end{tabular}

[a]Reaction conditions: substrate $(0.25 \mathrm{mmol})$, pre-catalyst $(0.3 \mathrm{~mol} \%)$, toluene $(0.5 \mathrm{M}), 17 \mathrm{~h}$. Average of 2 reactions; conversion determined by GC.

Table 6. Comparison of commercially available catalysts for olefin metathesis with $\mathbf{3 c}$. $^{\text {a }}$

\begin{tabular}{|c|c|c|c|c|c|c|}
\hline & \multirow[b]{2}{*}{ Product } & \multirow{2}{*}{$\begin{array}{l}\text { Catalyst } \\
\text { loading } \\
\text { (mol\%) }\end{array}$} & \multicolumn{4}{|c|}{ Isolated yields (\%) } \\
\hline & & & $3 c^{b}$ & Gru-IIc & Hov-II & $\begin{array}{c}c i s-\mathrm{Caz} \\
1^{\mathrm{b}}\end{array}$ \\
\hline $1^{\mathrm{e}}$ & & 0.3 & 98 & 38 & 88 & 92 \\
\hline 2 & & 1 & 91 & 18 & 56 & 55 \\
\hline 3 & & 5 & 93 & 4 & 53 & 45 \\
\hline
\end{tabular}

a Reaction conditions: substrate $(0.25 \mathrm{mmol})$, solvent $(0.5 \mathrm{M}), 24 \mathrm{~h}$. Average of 2 reactions; isolated yield. ${ }^{b}$ Toluene, $110^{\circ} \mathrm{C}$. ${ }^{\mathrm{c}}$ Dichloromethane, reflux. ${ }^{\mathrm{d}}$ Benzene, $60^{\circ} \mathrm{C}$. $17 \mathrm{~h}$.

In agreement with previous results employing mixed $\mathrm{NHC} /$ phosphite ruthenium complexes, ${ }^{16 a-c} \mathbf{3 c}$ was not active at low temperature and required thermal activation in the RCM of substrate 4. The best result was obtained at $110^{\circ} \mathrm{C}$. However, $80^{\circ} \mathrm{C}$ was also identified as an optimal temperature, as a conversion of $93 \%$ was observed. Lower reaction temperatures lead to operationally simpler reaction protocols. In order to fully assess the potential of $\mathbf{3 c}$, its catalytic activity was compared with state-of-the-art commercial pre-catalysts using three challenging RCM substrates, under the optimal conditions for each catalyst at the same Ru loading. ${ }^{28}$ As observed in Table 6, 3c is a superior catalyst to Gru-II, Hov-II and cis-Caz-1 and proved more efficient in the three transformations studied. Concerning the most reactive of these substrates leading to product 5 (Table 6, entry 1 ), the second-generation catalyst Gru-II afforded only $38 \%$ yield, whereas Hov-II and cis-Caz-1 achieved $88 \%$ and $92 \%$ respectively. In comparison, an excellent yield of $98 \%$ was achieved with 3c. It is worth mentioning that $3 \mathbf{c}$ surpasses the reported activity of complex $\left[\mathrm{Ru}(\mathrm{SITol})\left(=\mathrm{CHPhSCF}_{3}\right) \mathrm{Cl}_{2}\right]$ (Tol$\left.\mathbf{S C F}_{3}\right)^{29}$ a latent chelating catalyst that can be activated thermally and by UV irradiation. Tol- $\mathbf{S C F}_{3}$ is able to achieve $83 \%$ conversion of 5 with $0.4 \mathrm{~mol} \%$ under optimized conditions $\left(0.1 \mathrm{M}\right.$ toluene, $\left.80^{\circ} \mathrm{C}\right) .{ }^{29}$ The reactivity difference between the complexes becomes more significant for products 7 and $\mathbf{9}$. Here, the yields with $\mathbf{3 c}$ are almost twice as high as those obtained with Hov-II and cis-Caz-1, demonstrating the superior performance of this catalyst regardless of the substrate.

Finally, several benchmark substrates in a variety of metathesis transformations were studied in order to explore the tolerance of $\mathbf{3 c}$ towards different functionalities (Table 7 and Scheme 2). Reactions were conducted at $80^{\circ} \mathrm{C}$ and focused on low catalysts loading for usual molecules and on transformation of very difficult substrates. The RCM of less hindered malonate, tosylate and nitrile derivatives were easily performed with $0.02-0.1$ mol\% of catalyst (Table 7, entries 1 to 5). Unhindered six-membered compounds were obtained in a similar manner, in quantitative yield (Table 7, entries 6 and 7). We next focused our attention on challenging substrates which are usually not fully transformed under milder reaction conditions. Gratifyingly, tetra-substituted five- and sixmembered tosylates $\mathbf{5}$ and $\mathbf{2 5}$ were obtained respectively in 90 and $98 \%$ isolated yield, with 0.3 and 0.4 mol\% catalyst loading (Table 7, entries 8 and 9). RCM of substrate 6 was almost complete after 24 hours (Table 7 , entry 10). 7 is usually very difficult to obtain even with high catalyst loadings, therefore achieving such results highlights the outstanding catalytic activity of 3c. Even though the RCM of bis-nitrile $\mathbf{1 8}$ has been extensively reported, ${ }^{11 d, 30}$ the RCM of its tetra-substituted analogue has been scarcely studied. The only attempt reported so far gave 9 in 55\% isolated yield using 5 mol\% catalyst. ${ }^{16 c}$ Compound $\mathbf{8}$ is very challenging to convert as the nitrile functional group can interfere with the ruthenium metal center, slowing the reaction significantly. The formation of $\mathbf{9}$ obtained in high yield (81\%) using 5 mol\% of pre-catalyst 3c represents a considerable improvement. Investigations were extended to ring-closing enyne metathesis (RCEYM) where good results were obtained. The reaction reached completion for the first two experiments using respectively $0.1 \mathrm{~mol} \%$ and 2 mol\% of catalyst to afford compounds $\mathbf{2 7}$ and $\mathbf{2 9}$. However, no conversion was observed for challenging substrate $\mathbf{3 0}$, even with 5 mol\% catalyst loading. Cross metathesis reactions (CM) were then conducted on different substrates (Scheme 2). Reactions were performed with 3 equivalents of alkene partner (methyl acrylate) at $80^{\circ} \mathrm{C}$ with a lower concentration than for RCEYM and RCM (0.1M toluene) to avoid selfmetathesis of the substrate. $\mathrm{CM}$ is more challenging than other metathesis reactions as formation of side-products is more likely. All compounds were obtained in medium to good yield with 1-2 mol\% catalyst loading. 
Table 7. Experiments in RCM and enyne metathesis at low catalyst loading. ${ }^{a}$

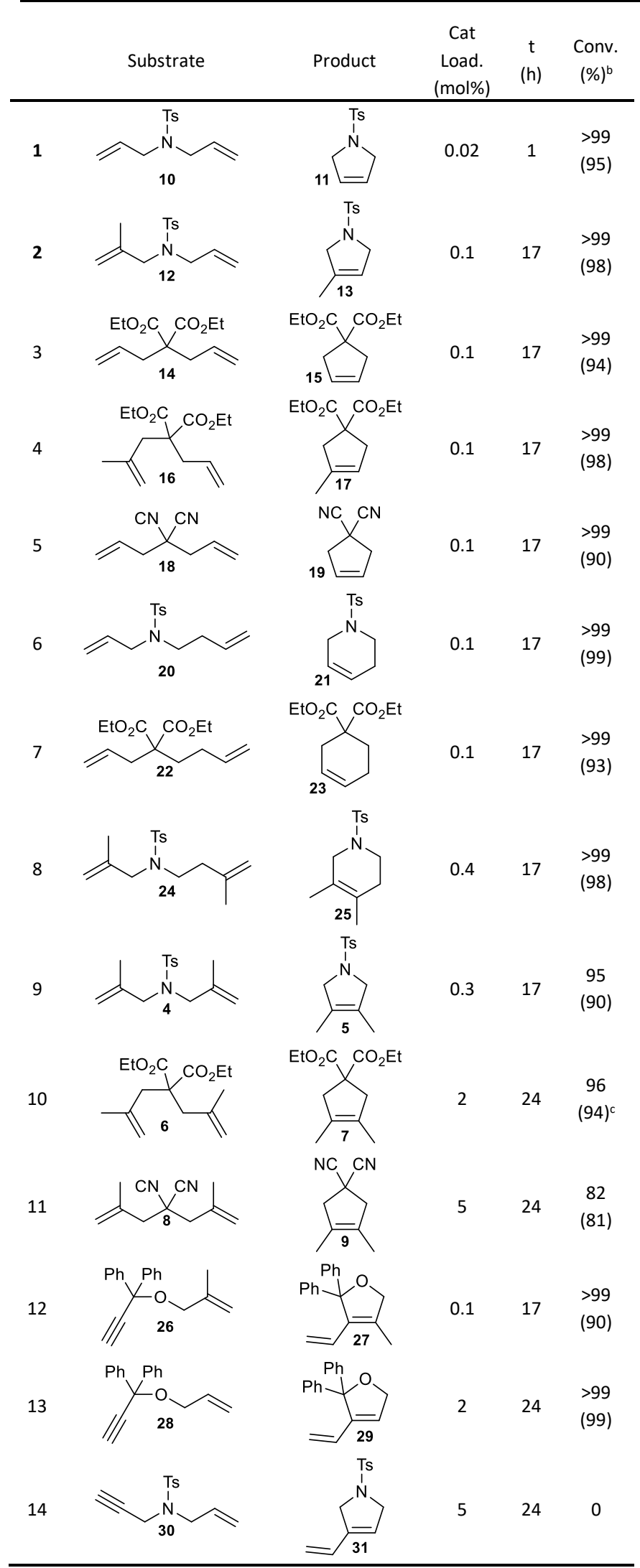

a Reaction conditions: substrate $(0.25 \mathrm{mmol})$, pre-catalyst, toluene $(0.5 \mathrm{M}), 80^{\circ} \mathrm{C}$, 1-24h. ${ }^{\text {b }}$ Average of 2 reactions; conversion determined by GC.

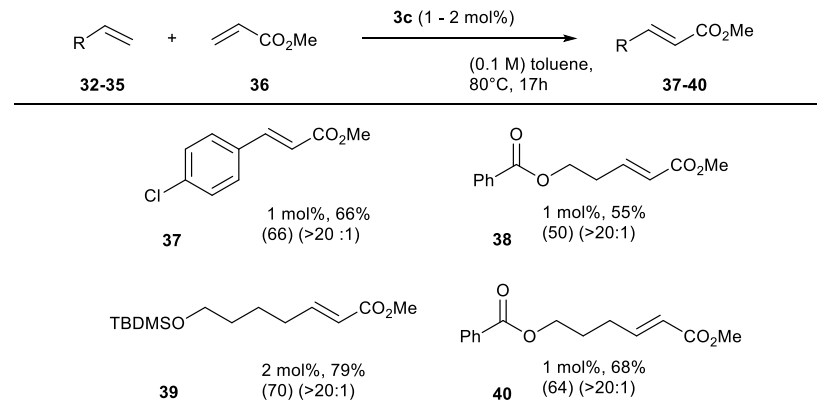

Scheme 2. Experiments in cross metathesis. ${ }^{a}$ Reaction conditions: substrate $(0.25 \mathrm{mmol})$, alkene partner $(0.75 \mathrm{mmol}), 3 \mathrm{c}(1-2 \mathrm{~mol} \%)$, toluene $(0.1 \mathrm{M}), 80^{\circ} \mathrm{C}$. Average of 2 reactions; isolated yield are given; $E / Z$ ratio in brackets.

\section{Conclusions}

We have shown that the electronic properties of the phosphite (sacrificial) ligand play a significant role on the activation/activity of the complex. By combining data from calorimetric experiments, X-ray structural studies and DFT calculations, it was possible to observe and rationalise the effects of electron withdrawing functional groups in the para position of the triphenyl phosphite ligand. Electronwithdrawing substituents increase the electrophilicity of the complex and increase overall reaction kinetics for RCM. Among this series of complexes, $\mathbf{3 c}$ emerged as a powerful catalyst displaying high efficiency and good functional group tolerance. It appears outstandingly effective at low catalyst loading in challenging ring closing metathesis transformations, comparing very favourably with well-known commercially available state-of-the-art ruthenium pre-catalysts for olefin metathesis.

\section{Experimental}

Detailed experimental procedures for the synthesis of phosphite ligands, substrates, catalytic transformations, and additional computational data can be found in the supporting information.

\section{Tri(p-pentafluorosulfurphenyl)phosphite (1e) $)^{32}$}

A Schlenk flask was charged with the corresponding $p$ pentafluorosulfurphenol $(1.0 \mathrm{~g}, 4.5 \mathrm{mmol})$, triethylamine $(1.2$ equiv., $800 \mu \mathrm{L}, 5.45 \mathrm{mmol}$ ) and diethylether $(50 \mathrm{~mL})$. The reaction mixture was stirred at room temperature under inert atmosphere for 1 hour. Phosphorus trichloride (0.33 equiv., $137 \mu \mathrm{L}, 1.51 \mathrm{mmol}$ ) was added dropwise. The reaction mixture was stirred at room temperature for 24 hours. The solvent was removed in vacuo. Resulting solid was dissolved in $30 \mathrm{~mL}$ of hexane and filtered on a pad of silica. The supernatant solution was then dried in vacuo. Tril $p$ pentafluorosulfurphenyl)phosphite was obtained as a colorless solid (0.76 g, 73\%). ${ }^{1} \mathrm{H}$ NMR (400 MHz, $\left.\mathrm{CD}_{2} \mathrm{Cl}_{2}, 298 \mathrm{~K}\right) \delta=7.78$ $\left(d,{ }^{3} J(\mathrm{H}, \mathrm{H})=9.5 \mathrm{~Hz}, 6 \mathrm{H}\right), 7.24\left(\mathrm{~d},{ }^{3} \mathrm{~J}(\mathrm{H}, \mathrm{H})=9.5 \mathrm{~Hz}, 6 \mathrm{H}\right) ;{ }^{13} \mathrm{C}-\{1 \mathrm{H}\}$ NMR (101 MHz, $\left.\mathrm{CD}_{2} \mathrm{Cl}_{2}, 298 \mathrm{~K}\right): \delta=153.6\left(\mathrm{~s}, \mathrm{C}_{p}\right), 150.2$ (d, 2J $\left.(C, P)=19.0 \mathrm{~Hz}, C_{i}\right), 128.5\left(p, J(C, F)=4.1 \mathrm{~Hz}, C_{m}\right), 120.9\left(d,{ }^{3} J\right.$ 
$\left.(\mathrm{C}, \mathrm{P})=7.2 \mathrm{~Hz}, \mathrm{C}_{o}\right) ;{ }^{31} \mathrm{P}-\left\{{ }^{1} \mathrm{H}\right\} \mathrm{NMR}\left(162 \mathrm{MHz}, \mathrm{CD}_{2} \mathrm{Cl}_{2}, 298 \mathrm{~K}\right): \delta=$ 125.3 .

General procedure for the synthesis of the $\left[\mathrm{RuCl}_{2}\left(\eta^{6}\right.\right.$-cymene)(P\{O$\left.\left.\mathrm{C}_{6} \mathrm{H}_{4}-\mathrm{p}-\mathrm{R}\right\}_{3}\right)$ ] complexes (2b-f) for calorimetry ${ }^{33}$

In a glovebox, a Schlenk flask was charged with $\left[\mathrm{Ru}(\mu-\mathrm{Cl}) \mathrm{Cl}\left(\eta^{6}\right.\right.$ cymene $)]_{2}(0.15 \mathrm{~g}, 0.24 \mathrm{mmol})$, the corresponding phosphite (0.49 mmol, 2 equiv.) and dichloromethane $(5 \mathrm{~mL})$. The reaction mixture was stirred 15 minutes at room temperature and concentrated in vacuo $(1 \mathrm{~mL})$. Hexane $(10 \mathrm{~mL})$ was added and the precipitate was collected by filtration and washed with hexane $(3 \times 3 \mathrm{~mL})$.

\section{[RuCl ${ }_{2}\left(\eta^{6}\right.$-cymene) $\left.\left\{\mathrm{P}\left(\mathrm{O}-\mathrm{C}_{6} \mathrm{H}_{4}-p-\mathrm{OMe}\right)_{3}\right\}\right](2 \mathrm{~b})$}

The general procedure afforded $\mathbf{2 b}$ in $82 \%$ yield $(284 \mathrm{mg}$ ) as a red solid. ${ }^{1} \mathrm{H}$ NMR $\left(400 \mathrm{MHz}, \mathrm{CD}_{2} \mathrm{Cl}_{2}, 298 \mathrm{~K}\right): \delta=7.18\left(\mathrm{~d},{ }^{3} \mathrm{~J}(\mathrm{H}, \mathrm{H})\right.$ $\left.=8.8 \mathrm{~Hz}, 6 \mathrm{H}, \mathrm{H}^{2}\right), 6.83\left(\mathrm{~d}, 3 \mathrm{~J}(\mathrm{H}, \mathrm{H})=8.8 \mathrm{~Hz}, 6 \mathrm{H}, \mathrm{H}^{3}\right), 5.41(\mathrm{~d}, 3 \mathrm{~J}$ $\left.(\mathrm{H}, \mathrm{H})=6.2 \mathrm{~Hz}, 2 \mathrm{H}, \mathrm{H}^{6}\right), 5.08\left(\mathrm{~d},{ }^{3} \mathrm{~J}(\mathrm{H}, \mathrm{H})=6.2 \mathrm{~Hz}, 2 \mathrm{H}, \mathrm{H}^{7}\right), 3.76$ $(\mathrm{s}, 9 \mathrm{H}, \mathrm{O}-\mathrm{Me}), 2.68\left(\mathrm{p}, 3 \mathrm{~J}(\mathrm{H}, \mathrm{H})=6.9 \mathrm{~Hz}, 1 \mathrm{H}, \mathrm{H}^{10}\right), 1.82(\mathrm{~s}, 3 \mathrm{H}$, $\left.\mathrm{H}^{11}\right), 1.18\left(\mathrm{~d},{ }^{3} J(\mathrm{H}, \mathrm{H})=6.9 \mathrm{~Hz}, 6 \mathrm{H}, \mathrm{H}^{9}\right) ;{ }^{13} \mathrm{C}-\left\{{ }^{1} \mathrm{H}\right\} \mathrm{NMR}(101 \mathrm{MHz}$, $\mathrm{CD}_{2} \mathrm{Cl}_{2}, 298 \mathrm{~K}$ ): $\delta=157.2\left(\mathrm{~s}, \mathrm{C}^{4}\right), 145.5\left(\mathrm{~d}, 2 J(\mathrm{C}, \mathrm{P})=11.2 \mathrm{~Hz}, \mathrm{C}^{1}\right)$, $122.8\left(\mathrm{~d},{ }^{3} \mathrm{~J}(\mathrm{C}, \mathrm{P})=3.7 \mathrm{~Hz}, \mathrm{C}^{2}\right), 114.7\left(\mathrm{~s}, \mathrm{C}^{3}\right), 109.5\left(\mathrm{~s}, \mathrm{C}^{5}\right), 103.5$ $\left(\mathrm{s}, \mathrm{C}^{8}\right), 89.2\left(\mathrm{~m}, \mathrm{C}^{6}\right.$ and $\left.\mathrm{C}^{7}\right), 56.0(\mathrm{~s}, \mathrm{O}-\mathrm{Me}), 31.0\left(\mathrm{~s}, \mathrm{C}^{10}\right), 22.3(\mathrm{~s}$, $\left.\mathrm{C}^{9}\right), 18.3$ (s, C ${ }^{11}$ );. ${ }^{31} \mathrm{P}-\left\{{ }^{1} \mathrm{H}\right\}$ NMR (121 MHz, $\left.\mathrm{CD}_{2} \mathrm{Cl}_{2}, 298 \mathrm{~K}\right): \delta=$ 107.3. Elemental Analysis Calcd (\%) for $\mathrm{C}_{31} \mathrm{H}_{35} \mathrm{Cl}_{2} \mathrm{O}_{6} \mathrm{PRu}$ : $\mathrm{C}$ 52.70, H 4.99; Found: C 52.69, H 5.03.

\section{[RuCl ${ }_{2}\left(\eta^{6}\right.$-cymene $\left.)\left\{\mathrm{P}\left(\mathrm{O}-\mathrm{C}_{6} \mathrm{H}_{4}-p-\mathrm{CF}_{3}\right)_{3}\right\}\right](2 \mathrm{c})$}

The general procedure afforded $\mathbf{2 c}$ in $97 \%$ yield $(391 \mathrm{mg}$ ) as an orange solid. ${ }^{1} \mathrm{H} \mathrm{NMR}\left(400 \mathrm{MHz}, \mathrm{CD}_{2} \mathrm{Cl}_{2}, 298 \mathrm{~K}\right): \delta=7.63$ (d, ${ }^{3} \mathrm{~J}$ $\left.(\mathrm{H}, \mathrm{H})=8.3 \mathrm{~Hz}, 6 \mathrm{H}, \mathrm{H}^{3}\right), 7.43\left(\mathrm{~d}, 3 \mathrm{~J}(\mathrm{H}, \mathrm{H})=8.3 \mathrm{~Hz}, 6 \mathrm{H}, \mathrm{H}^{2}\right), 5.49$ $\left(d,{ }^{3} J(H, H)=6.1 \mathrm{~Hz}, 2 \mathrm{H}, \mathrm{H}^{6}\right), 5.22\left(\mathrm{~d}, 3 \mathrm{~J}(\mathrm{H}, \mathrm{H})=6.1 \mathrm{~Hz}, 2 \mathrm{H}, \mathrm{H}^{7}\right)$, $2.67\left(\mathrm{p}, 3 \mathrm{~J}(\mathrm{H}, \mathrm{H})=7.0 \mathrm{~Hz}, 1 \mathrm{H}, \mathrm{H}^{10}\right), 1.82\left(\mathrm{~s}, 3 \mathrm{H}, \mathrm{H}^{11}\right), 1.18(\mathrm{~d}, 3 \mathrm{~J}$ $\left.(\mathrm{H}, \mathrm{H})=7.0 \mathrm{~Hz}, 6 \mathrm{H}, \mathrm{H}^{9}\right) ;{ }^{13} \mathrm{C}-\left\{{ }^{1} \mathrm{H}\right\} \mathrm{NMR}\left(101 \mathrm{MHz}, \mathrm{CD}_{2} \mathrm{Cl}_{2}, 298 \mathrm{~K}\right)$ : $\delta=154.1\left(\mathrm{~d}, J(\mathrm{C}, \mathrm{P})=11.2 \mathrm{~Hz}, \mathrm{C}^{1}\right), 127.9(\mathrm{~d}, J(\mathrm{C}, \mathrm{P})=33.0 \mathrm{~Hz}$, $\left.C^{3}\right), 127.5\left(q, J(C, F)=3.7 \mathrm{~Hz}, C^{4}\right), 124.3(q, J(C, F)=272.7 \mathrm{~Hz}$, $\left.\mathrm{CF}_{3}\right), 122.3\left(\mathrm{~d}, 3 \mathrm{~J}(\mathrm{C}, \mathrm{P})=4.2 \mathrm{~Hz}, \mathrm{C}^{2}\right), 111.4\left(\mathrm{~s}, \mathrm{C}^{5}\right), 103.8\left(\mathrm{~s}, \mathrm{C}^{8}\right)$, $90.5\left(\mathrm{~d}, J(C, P)=7.1 \mathrm{~Hz}, \mathrm{C}^{7}\right), 89.8\left(\mathrm{~d}, J(\mathrm{C}, \mathrm{P})=6.5 \mathrm{~Hz}, \mathrm{C}^{6}\right), 31.1(\mathrm{~s}$, $\left.\mathrm{C}^{10}\right), 22.1\left(\mathrm{~s}, \mathrm{C}^{9}\right), 18.2\left(\mathrm{~s}, \mathrm{C}^{11}\right) ;{ }^{31 \mathrm{P}-}\{1 \mathrm{H}\}$ NMR $\left(162 \mathrm{MHz}, \mathrm{CD}_{2} \mathrm{Cl}_{2}\right.$, 298K): $\delta=106.8$; Elemental Analysis Calcd (\%) for $\mathrm{C}_{31} \mathrm{H}_{26} \mathrm{Cl}_{2} \mathrm{~F}_{9} \mathrm{O}_{3} \mathrm{PRu}$ : C 45.38, H 3.19; Found: C 45.19, H 3.10.

\section{[RuCl ${ }_{2}\left(\eta^{6}\right.$-cymene $\left.)\left\{\mathrm{P}\left(\mathrm{O}-\mathrm{C}_{6} \mathrm{H}_{4}-p-\mathrm{Cl}\right)_{3}\right\}\right](2 \mathrm{~d})$}

The general procedure afforded $\mathbf{2} \mathbf{d}$ in $99 \%$ yield $(352 \mathrm{mg}$ ) as a pink solid. ${ }^{1} \mathrm{H} \mathrm{NMR}\left(400 \mathrm{MHz}, \mathrm{CD}_{2} \mathrm{Cl}_{2}, 298 \mathrm{~K}\right.$ ): $\delta=7.27$ (dd, ${ }^{4} \mathrm{~J}$ $(\mathrm{H}, \mathrm{H})=0.8 \mathrm{~Hz}, 3 \mathrm{~J}(\mathrm{H}, \mathrm{H})=8.7 \mathrm{~Hz}, 12 \mathrm{H}, \mathrm{H}^{2}$ and $\left.\mathrm{H}^{3}\right), 5.46(\mathrm{~d}, 3 \mathrm{~J}$ $\left.(\mathrm{H}, \mathrm{H})=6.0 \mathrm{~Hz}, 2 \mathrm{H}, \mathrm{H}^{6}\right), 5.16\left(\mathrm{~d},{ }^{3} \mathrm{~J}(\mathrm{H}, \mathrm{H})=6.0 \mathrm{~Hz}, 2 \mathrm{H}, \mathrm{H}^{7}\right), 2.69$ $\left(p,{ }^{3} J(H, H)=7.1 \mathrm{~Hz}, 1 \mathrm{H}, \mathrm{H}^{10}\right), 1.84\left(\mathrm{~s}, 3 \mathrm{H}, \mathrm{H}^{11}\right), 1.19\left(\mathrm{~d},{ }^{3} \mathrm{~J}(\mathrm{H}, \mathrm{H})\right.$ $\left.=7.1 \mathrm{~Hz}, 6 \mathrm{H}, \mathrm{H}^{9}\right) ;{ }^{13} \mathrm{C}-\{1 \mathrm{H}\}$ NMR $\left(101 \mathrm{MHz}, \mathrm{CD}_{2} \mathrm{Cl}_{2}, 298 \mathrm{~K}\right): \delta=$ $150.2\left(\mathrm{~d},{ }^{3} \mathrm{~J}(\mathrm{C}, \mathrm{P})=11.0 \mathrm{~Hz}, \mathrm{C}^{1}\right), 131.0\left(\mathrm{~s}, \mathrm{C}^{4}\right), 130.0\left(\mathrm{~s}, \mathrm{C}^{3}\right)$, $123.4\left(d,{ }^{3} J(C, P)=4.0 \mathrm{~Hz}, C^{2}\right), 110.6\left(s, C^{5}\right), 104.0\left(s, C^{8}\right), 89.8$ $\left(\mathrm{d}, J(C, P)=6.9 \mathrm{~Hz}, \mathrm{C}^{7}\right), 89.7\left(\mathrm{~d}, J(\mathrm{C}, \mathrm{P})=6.1 \mathrm{~Hz}, \mathrm{C}^{6}\right), 31.1(\mathrm{~s}$, $\left.\mathrm{C}^{10}\right), 22.2\left(\mathrm{~s}, \mathrm{C}^{9}\right), 18.3\left(\mathrm{~s}, \mathrm{C}^{11}\right) ;{ }^{11} \mathrm{P}-\left\{{ }^{1} \mathrm{H}\right\}$ NMR $\left(121 \mathrm{MHz}, \mathrm{CD}_{2} \mathrm{Cl}_{2}\right.$, 298K): $\delta=107.2$; Elemental Analysis Calcd (\%) for $\mathrm{C}_{28} \mathrm{H}_{26} \mathrm{Cl}_{5} \mathrm{O}_{3} \mathrm{PRu}$ : $\mathrm{C} 46.72, \mathrm{H}$ 3.64; Found: $\mathrm{C} 46.70, \mathrm{H}$ 3.53.

\section{[RuCl ${ }_{2}\left(\eta^{6}\right.$-cymene) $\left.\left\{\mathrm{P}\left(\mathrm{O}-\mathrm{C}_{6} \mathrm{H}_{4}-\boldsymbol{p}-\mathrm{SF}_{5}\right)_{3}\right\}\right](2 \mathrm{e})$}

The general procedure afforded $2 \mathbf{e}$ in $93 \%$ yield $(451 \mathrm{mg})$ as an orange solid. ${ }^{1} \mathrm{H}$ NMR $\left(400 \mathrm{MHz}, \mathrm{CD}_{2} \mathrm{Cl}_{2}, 298 \mathrm{~K}\right): \delta=7.76\left(\mathrm{~d},{ }^{3} \mathrm{~J}\right.$ $\left.(\mathrm{H}, \mathrm{H})=8.6 \mathrm{~Hz}, 6 \mathrm{H}, \mathrm{H}^{3}\right), 7.41\left(\mathrm{~d}, 3 \mathrm{~J}(\mathrm{H}, \mathrm{H})=8.6 \mathrm{~Hz}, 6 \mathrm{H}, \mathrm{H}^{2}\right), 5.50$ $\left.\left(d,{ }^{3}\right)(H, H)=5.8 \mathrm{~Hz}, 2 \mathrm{H}, \mathrm{H}^{6}\right), 5.28\left(\mathrm{~d},{ }^{3} \mathrm{~J}(\mathrm{H}, \mathrm{H})=5.8 \mathrm{~Hz}, 2 \mathrm{H}, \mathrm{H}^{7}\right)$, $2.64\left(\mathrm{p}, 3 \mathrm{~J}(\mathrm{H}, \mathrm{H})=7.0 \mathrm{~Hz}, 1 \mathrm{H}, \mathrm{H}^{10}\right), 1.84\left(\mathrm{~s}, 3 \mathrm{H}, \mathrm{H}^{11}\right), 1.18(\mathrm{~d}, 3 \mathrm{~J}$
$\left.(\mathrm{H}, \mathrm{H})=7.0 \mathrm{~Hz}, 6 \mathrm{H}, \mathrm{H}^{9}\right) ;{ }^{13} \mathrm{C}-\left\{{ }^{1} \mathrm{H}\right\} \mathrm{NMR}\left(101 \mathrm{MHz}, \mathrm{CD}_{2} \mathrm{Cl}_{2}, 298 \mathrm{~K}\right)$ : $\delta=153.3\left(\mathrm{~d}, J(\mathrm{C}, \mathrm{P})=10.7 \mathrm{~Hz}, \mathrm{C}^{1}\right), 150.8(\mathrm{~m}, J(\mathrm{C}, \mathrm{P})=18.2 \mathrm{~Hz}$, $\left.\mathrm{C}^{3}\right), 128.2\left(\mathrm{~m}, 3 J(\mathrm{C}, \mathrm{F})=5.1 \mathrm{~Hz}, \mathrm{C}^{4}\right), 122.1\left(\mathrm{~d}, J(\mathrm{C}, \mathrm{P})=4.3 \mathrm{~Hz}, \mathrm{C}^{2}\right)$, $111.8\left(\mathrm{~s}, \mathrm{C}^{5}\right), 103.8\left(\mathrm{~s}, \mathrm{C}^{8}\right), 91.0\left(\mathrm{~d}, J(\mathrm{C}, \mathrm{P})=7.0 \mathrm{~Hz}, \mathrm{C}^{7}\right), 89.9$ (d, J $\left.(C, P)=6.8 \mathrm{~Hz}, \mathrm{C}^{6}\right), 31.2\left(\mathrm{~s}, \mathrm{C}^{10}\right), 22.1\left(\mathrm{~s}, \mathrm{C}^{9}\right), 18.2\left(\mathrm{~s}, \mathrm{C}^{11}\right)$; ${ }^{31} \mathrm{P}-$ $\{1 \mathrm{H}\}$ NMR (121 MHz, $\left.\mathrm{CD}_{2} \mathrm{Cl}_{2}, 298 \mathrm{~K}\right): \delta=107.6$; Elemental Analysis Calcd (\%) for $\mathrm{C}_{28} \mathrm{H}_{26} \mathrm{Cl}_{2} \mathrm{~F}_{15} \mathrm{O}_{3} \mathrm{PRuS}_{3}$ : C 33.81, H 2.63; Found: C 33.75, $\mathrm{H} 2.57$.

\section{[RuCl $2\left(\eta^{6}\right.$-cymene) $\left.\left\{\mathrm{P}\left(\mathrm{O}-\mathrm{C}_{6} \mathrm{H}_{4}-\boldsymbol{p}-\mathrm{CN}\right)_{3}\right\}\right]$ (2f)}

The general procedure afforded $\mathbf{2} \mathbf{f}$ in $95 \%$ yield $(314 \mathrm{mg}$ ) as a red solid. ${ }^{1} \mathrm{H}$ NMR $\left(400 \mathrm{MHz}, \mathrm{CD}_{2} \mathrm{Cl}_{2}, 298 \mathrm{~K}\right): \delta=7.67\left(\mathrm{~d},{ }^{3} \mathrm{~J}(\mathrm{H}, \mathrm{H})\right.$ $\left.=8.4 \mathrm{~Hz}, 6 \mathrm{H}, \mathrm{H}^{3}\right), 7.40\left(\mathrm{~d}, 3 \mathrm{~J}(\mathrm{H}, \mathrm{H})=8.4 \mathrm{~Hz}, 6 \mathrm{H}, \mathrm{H}^{2}\right), 5.53(\mathrm{~d}, 3 \mathrm{~J}$ $\left.(H, H)=6.2 \mathrm{~Hz}, 2 \mathrm{H}, \mathrm{H}^{6}\right), 5.23\left(\mathrm{~d},{ }^{3} \mathrm{~J}(\mathrm{H}, \mathrm{H})=6.2 \mathrm{~Hz}, 2 \mathrm{H}, \mathrm{H}^{7}\right), 2.73$ $\left.(p, 3)(H, H)=7.0 \mathrm{~Hz}, 1 \mathrm{H}, \mathrm{H}^{10}\right), 1.85\left(\mathrm{~s}, 3 \mathrm{H}, \mathrm{H}^{11}\right), 1.20(\mathrm{~d}, 3 \mathrm{~J}(\mathrm{H}, \mathrm{H})$ $\left.=7.0 \mathrm{~Hz}, 6 \mathrm{H}, \mathrm{H}^{9}\right) ;{ }^{13} \mathrm{C}-\left\{{ }^{1} \mathrm{H}\right\} \mathrm{NMR}\left(101 \mathrm{MHz}, \mathrm{CD}_{2} \mathrm{Cl}_{2}, 298 \mathrm{~K}\right): \delta=$ $154.5\left(\mathrm{~d}, J(\mathrm{C}, \mathrm{P})=10.9 \mathrm{~Hz}, \mathrm{C}^{1}\right), 134.4\left(\mathrm{~s}, \mathrm{C}^{3}\right), 122.8(\mathrm{~d}, J(\mathrm{C}, \mathrm{P})=$ $\left.4.3 \mathrm{~Hz}, \mathrm{C}^{2}\right), 118.4(\mathrm{~s}, \mathrm{CN}), 111.6\left(\mathrm{~s}, \mathrm{C}^{5}\right), 109.9$ (s, C4), 104.8 (s, $\left.C^{8}\right), 90.4\left(d, J(C, P)=6.5 \mathrm{~Hz}, C^{7}\right), 90.3\left(d, J(C, P)=6.2 \mathrm{~Hz}, C^{6}\right)$, $31.2\left(\mathrm{~s}, \mathrm{C}^{10}\right), 22.1\left(\mathrm{~s}, \mathrm{C}^{9}\right), 18.4\left(\mathrm{~s}, \mathrm{C}^{11}\right) ;{ }^{31} \mathrm{P}-\left\{{ }^{1} \mathrm{H}\right\} \mathrm{NMR}(162 \mathrm{MHz}$, $\mathrm{CD}_{2} \mathrm{Cl}_{2}, 298 \mathrm{~K}$ ): $\delta=107.2$; Elemental Analysis Calcd (\%) for $\mathrm{C}_{31} \mathrm{H}_{26} \mathrm{Cl}_{2} \mathrm{~N}_{3} \mathrm{O}_{3}$ PRu: $\mathrm{C} 53.84, \mathrm{H}$ 3.79, N 6.08; Found: C 53.72, H 3.72, N 5.98.

\section{General procedure for the synthesis of mixed NHC/phosphite ruthenium-based complexes $(3 a-f)^{34}$}

A Schlenk flask was charged with $\left[\mathrm{RuCl}_{2}(\mathrm{Ind})(\mathrm{Py})(\mathrm{SIMes})\right]$ Ind-III ( $0.5 \mathrm{~g}, 0.668 \mathrm{mmol})$, the phosphite $(0.801 \mathrm{mmol}, 1.2 \mathrm{eq})$ and dichloromethane (8 $\mathrm{mL}$, 3a-d) or dichloroethane (3e-f) under $\mathrm{N}_{2}$ atmosphere. The reaction was stirred at $40^{\circ} \mathrm{C}(3 \mathrm{a}-\mathrm{d})$ or $60^{\circ} \mathrm{C}$ (3e-f) during 15 hours and concentrated to $1 \mathrm{~mL}$ in vacuo. Pentane $(10 \mathrm{~mL})$ was added; the product was collected by filtration, washed with pentane $(3 \times 3 \mathrm{~mL})$ and methanol $(3 \times 1$ $\mathrm{mL})$, and obtained as a dark brown solid.

Dichloro-\{ $N, N^{\prime}$-bis[2,4,6-(trimethyl)phenyl]imidazolin-2-ylidene $\}$ Indenylidene)( $\boldsymbol{p}$-methoxytriphenylphosphite) ruthenium (3b)

$67 \%$ yield, $479 \mathrm{mg} .{ }^{1} \mathrm{H}$ NMR (300 MHz, $\mathrm{CD}_{2} \mathrm{Cl}_{2}, 233 \mathrm{~K}$ ): $\delta=8.61$ $\left(d, 3 J(H, H)=7.6 \mathrm{~Hz}, 1 \mathrm{H}, \mathrm{H}^{7}\right), 7.49-7.43\left(\mathrm{~m}, 3 \mathrm{H}, \mathrm{H}^{10}\right.$ and $\left.\mathrm{H}^{11}\right)$, 7.40-7.28 (m, $4 \mathrm{H}, \mathrm{H}^{5}, \mathrm{H}^{4}$ and $\left.\mathrm{H}^{9}\right), 7.34(\mathrm{~s}, 1 \mathrm{H}, \mathrm{CH}$ Mes), $7.22(\mathrm{t}$, 3J $\left.(\mathrm{H}, \mathrm{H})=7.6 \mathrm{~Hz}, 1 \mathrm{H}, \mathrm{H}^{6}\right), 7.08\left(\mathrm{~d},{ }^{3} \mathrm{~J}(\mathrm{H}, \mathrm{H})=8.8 \mathrm{~Hz}, 3 \mathrm{H}, \mathrm{H}_{\text {meta }}\right.$ $\mathrm{C}_{6} \mathrm{H}_{4}$ and $\mathrm{CH}$ Mes), $6.93\left(\mathrm{~d}, 3 \mathrm{~J}(\mathrm{H}, \mathrm{H})=8.8 \mathrm{~Hz}, 2 \mathrm{H}, \mathrm{H}_{\text {ortho }} \mathrm{C}_{6} \mathrm{H}_{4}\right)$, $6.58\left(\mathrm{~d}, 3 \mathrm{~J}(\mathrm{H}, \mathrm{H})=8.8 \mathrm{~Hz}, 2 \mathrm{H}, \mathrm{H}_{\text {meta }} \mathrm{C}_{6} \mathrm{H}_{4}\right), 6.39(\mathrm{~d}, 3 \mathrm{~J}(\mathrm{H}, \mathrm{H})=8.8$ $\left.\mathrm{Hz}, 2 \mathrm{H}, \mathrm{H}_{\text {ortho }} \mathrm{C}_{6} \mathrm{H}_{4}\right), 6.18\left(\mathrm{~s}, 2 \mathrm{H}, \mathrm{CH}\right.$ Mes), $6.11\left(\mathrm{~d},{ }^{3} \mathrm{~J}(\mathrm{H}, \mathrm{H})=8.8\right.$ $\left.\mathrm{Hz}, 2 \mathrm{H}, \mathrm{H}_{\text {ortho }} \mathrm{C}_{6} \mathrm{H}_{4}\right), 6.05\left(\mathrm{~s}, 1 \mathrm{H}, \mathrm{H}^{2}\right), 5.63(\mathrm{~d}, 3 \mathrm{~J}(\mathrm{H}, \mathrm{H})=8.8 \mathrm{~Hz}$, $\left.2 \mathrm{H}, \mathrm{H}_{\text {meta }} \mathrm{C}_{6} \mathrm{H}_{4}\right), 4.02-3.63\left(\mathrm{~m}, 4 \mathrm{H}, \mathrm{H}^{4^{\prime}}\right.$ and $\left.\mathrm{H}^{5^{\prime}}\right), 3.88(\mathrm{~s}, 3 \mathrm{H}, \mathrm{O}-$ $\mathrm{Me}), 3.65$ (s, 3H, O-Me), 3.04 (s, 3H, O-Me), 2.75 (s, 3H, $\left.\mathrm{CH}_{3}\right)$, $2.63\left(\mathrm{~s}, 3 \mathrm{H}, \mathrm{CH}_{3}\right), 2.42\left(\mathrm{~s}, 3 \mathrm{H}, \mathrm{CH}_{3}\right), 2.11\left(\mathrm{~s}, 3 \mathrm{H}, \mathrm{CH}_{3}\right), 1.90(\mathrm{~s}$, $\left.3 \mathrm{H}, \mathrm{CH}_{3}\right), 1.48\left(\mathrm{~s}, 3 \mathrm{H}, \mathrm{CH}_{3}\right) ;{ }^{13} \mathrm{C}-\{1 \mathrm{H}\} \mathrm{NMR}\left(75 \mathrm{MHz}, \mathrm{CD}_{2} \mathrm{Cl}_{2}\right.$, 233K): $\delta=292.6\left(\mathrm{~d},{ }^{2} J(\mathrm{C}, \mathrm{P})=25.1 \mathrm{~Hz}, \mathrm{C}^{1}\right), 206.1\left(\mathrm{~d},{ }^{2} J(\mathrm{C}, \mathrm{P})=\right.$ $13.6 \mathrm{~Hz}, \mathrm{C}^{\prime}$ ), $156.4\left(\mathrm{~s}, \mathrm{C}_{\text {para }} \mathrm{C}_{6} \mathrm{H}_{4}\right), 155.5\left(\mathrm{~s}, \mathrm{C}_{\text {para }} \mathrm{C}_{6} \mathrm{H}_{4}\right), 155.2(\mathrm{~s}$, $\left.\mathrm{C}_{\text {para }} \mathrm{C}_{6} \mathrm{H}_{4}\right), 145.5\left(\mathrm{~d}, 2 \mathrm{~J}(\mathrm{C}, \mathrm{P})=18.9 \mathrm{~Hz}, \mathrm{C}_{\text {ipso }} \mathrm{C}_{6} \mathrm{H}_{4}\right), 143.9(\mathrm{~d}, 2 \mathrm{~J}$ $\left.(\mathrm{C}, \mathrm{P})=4.9 \mathrm{~Hz} \mathrm{C}_{\text {ipso }} \mathrm{C}_{6} \mathrm{H}_{4}\right), 143.8\left(\mathrm{~d},{ }^{2} \mathrm{~J}(\mathrm{C}, \mathrm{P})=3.1 \mathrm{~Hz} \mathrm{C}_{\text {ipso }} \mathrm{C}_{6} \mathrm{H}_{4}\right)$, $141.7\left(\mathrm{~s}, \mathrm{C}^{\mathrm{IV}}\right), 140.6\left(\mathrm{~s}, \mathrm{C}^{\mathrm{IV}}\right), 139.4\left(\mathrm{~s}, \mathrm{C}^{\mathrm{IV}}\right), 138.7\left(\mathrm{~d},{ }^{2} \mathrm{~J}(\mathrm{C}, \mathrm{P})=\right.$ $13.4 \mathrm{~Hz}, \mathrm{C}^{2}$ ), 138.6 (s, CIV), 138.4 (s, CIV), 138.2 (s, CIV), 137.6 (s, $\left.\mathrm{ClV}^{\mathrm{IV}}\right), 136.4\left(\mathrm{~s}, \mathrm{C}^{\mathrm{IV}}\right), 136.2\left(\mathrm{~s}, \mathrm{C}^{\mathrm{IV}}\right), 135.6\left(\mathrm{~s}, \mathrm{C}^{\mathrm{IV}}\right), 134.9\left(\mathrm{~s}, \mathrm{C}^{\mathrm{IV}}\right)$, 133.4 (s, CIV), 130.0 (s, CH Mes), 129.9 (s, CH Mes), 129.8 (s, CH Mes), $129.6\left(\mathrm{~d},{ }^{3} \mathrm{~J}(\mathrm{C}, \mathrm{P})=6.6 \mathrm{~Hz}, \mathrm{CH}_{\text {ortho }} \mathrm{C}_{6} \mathrm{H}_{4}\right.$ and $\left.\mathrm{C}^{6}\right), 129.1$ (s, $\left.\mathrm{C}^{5}\right), 128.7\left(\mathrm{~s}, \mathrm{C}^{10}\right), 128.3\left(\mathrm{~s}, \mathrm{C}^{9}\right.$ and $\left.\mathrm{C}^{4}\right), 123.5$ (s, $\left.\mathrm{CH}_{\text {ortho }} \mathrm{C}_{6} \mathrm{H}_{4}\right)$, 121.7 (s, $\mathrm{C}^{11}$ ), 121.6 (s, $\left.\mathrm{CH}_{\text {ortho }} \mathrm{C}_{6} \mathrm{H}_{4}\right), 117.1$ (s, $\mathrm{CH}_{\text {ortho }} \mathrm{C}_{6} \mathrm{H}_{4}$ ), 
114.5 (s, $\mathrm{CH}_{\text {meta }} \mathrm{C}_{6} \mathrm{H}_{4}$ ), 113.2 (s, $\mathrm{CH}_{\text {meta }} \mathrm{C}_{6} \mathrm{H}_{4}$ ), 112.5 (s, $\mathrm{CH}_{\text {meta }}$ $\left.\mathrm{C}_{6} \mathrm{H}_{4}\right), 55.6\left(\mathrm{~s}, \mathrm{O}-\mathrm{CH}_{3}\right), 55.2\left(\mathrm{~s}, \mathrm{O}-\mathrm{CH}_{3}\right), 54.5\left(\mathrm{~s}, \mathrm{O}-\mathrm{CH}_{3}\right), 52.4(\mathrm{~s}$, $\left.\mathrm{C}^{\prime}\right)$ ), $51.4\left(\mathrm{~s}, \mathrm{C}^{4^{\prime}}\right), 21.0\left(\mathrm{~s}, \mathrm{CH}_{3}\right), 20.7\left(\mathrm{~s}, \mathrm{CH}_{3}\right), 20.5\left(\mathrm{~s}, \mathrm{CH}_{3}\right), 19.0$ (s, $\left.\mathrm{CH}_{3}\right), 18.9$ (s, $\left.\mathrm{CH}_{3}\right), 18.6$ (s, $\left.\mathrm{CH}_{3}\right) ;{ }^{31} \mathrm{P}-\{1 \mathrm{H}\} \mathrm{NMR}(162 \mathrm{MHz}$, $\left.\mathrm{CD}_{2} \mathrm{Cl}_{2}, 233 \mathrm{~K}\right): \quad \delta=116.1$; Elemental Analysis Calcd (\%) for $\mathrm{C}_{57} \mathrm{H}_{57} \mathrm{Cl}_{2} \mathrm{~N}_{2} \mathrm{O}_{6} \mathrm{PRu}$ : C 64.04, H 5.37, N 2.62; Found: C 64.05, H 5.26, N 2.57.

Dichloro-\{N, $N^{\prime}$-bis[2,4,6-(trimethyl)phenyl]imidazolin-2-ylidene\} Indenylidene)( $p$-trifluoromethyltriphenylphosphite) ruthenium (3c)

$61 \%$ yield, $479 \mathrm{mg} .{ }^{1} \mathrm{H}$ NMR (300 MHz, $\mathrm{CD}_{2} \mathrm{Cl}_{2}, 233 \mathrm{~K}$ ): $\delta=8.59$ $\left(\mathrm{d}, 3 \mathrm{~J}(\mathrm{H}, \mathrm{H})=7.3 \mathrm{~Hz}, 1 \mathrm{H}, \mathrm{H}^{7}\right), 7.92\left(\mathrm{~d}, 3 \mathrm{~J}(\mathrm{H}, \mathrm{H})=8.5 \mathrm{~Hz}, 2 \mathrm{H}, \mathrm{H}_{\text {meto }}\right.$ $\left.\mathrm{C}_{6} \mathrm{H}_{4}\right), 7.65\left(\mathrm{~d}, 3^{3} \mathrm{~J}(\mathrm{H}, \mathrm{H})=8.3 \mathrm{~Hz}, 2 \mathrm{H}, \mathrm{H}_{\text {ortho }} \mathrm{C}_{6} \mathrm{H}_{4}\right), 7.47\left(\mathrm{t},{ }^{3} \mathrm{~J}(\mathrm{H}, \mathrm{H})\right.$ $\left.=7.3 \mathrm{~Hz}, 1 \mathrm{H}, \mathrm{H}^{11}\right), 7.40-7.36\left(\mathrm{~m}, 4 \mathrm{H}, \mathrm{H}^{9}\right.$ and $\left.\mathrm{H}^{10}\right), 7.31(\mathrm{~d}, 3 \mathrm{~J}$ $\left.(\mathrm{H}, \mathrm{H})=7.3 \mathrm{~Hz}, 1 \mathrm{H}, \mathrm{H}^{6}\right), 7.25-7.21\left(\mathrm{~m}, 3 \mathrm{H}, 2 \mathrm{H}_{\text {meta }} \mathrm{C}_{6} \mathrm{H}_{4}\right.$ and $\left.\mathrm{H}^{5}\right)$, 7.11 (s, 1H, CH Mes), 6.96 (s, 1H, CH Mes), 6.87 (d, 3J $(\mathrm{H}, \mathrm{H})=$ $\left.7.3 \mathrm{~Hz}, 1 \mathrm{H}, \mathrm{H}^{4}\right), 6.65\left(\mathrm{~d},{ }^{3} \mathrm{~J}(\mathrm{H}, \mathrm{H})=8.3 \mathrm{~Hz}, 2 \mathrm{H}, \mathrm{H}_{\text {ortho }} \mathrm{C}_{6} \mathrm{H}_{4}\right), 6.48$ $\left(\mathrm{d}, 3 \mathrm{~J}(\mathrm{H}, \mathrm{H})=8.3 \mathrm{~Hz}, 2 \mathrm{H}, \mathrm{H}_{\text {meta }} \mathrm{C}_{6} \mathrm{H}_{4}\right), 6.37(\mathrm{~d}, 3 \mathrm{~J}(\mathrm{H}, \mathrm{H})=8.3 \mathrm{~Hz}$, $\left.2 \mathrm{H}, \mathrm{H}_{\text {ortho }} \mathrm{C}_{6} \mathrm{H}_{4}\right), 6.24$ (s, $1 \mathrm{H}, \mathrm{CH}$ Mes), 6.11 (s, 1H, CH Mes), $6.00\left(\mathrm{~s}, 1 \mathrm{H}, \mathrm{H}^{2}\right), 4.06-3.73\left(\mathrm{~m}, 4 \mathrm{H}, \mathrm{H}^{4^{\prime}}, \mathrm{H}^{5^{\prime}}\right), 2.74\left(\mathrm{~s}, 3 \mathrm{H}, \mathrm{CH}_{3}\right)$, 2.61(s, 3H, $\left.\mathrm{CH}_{3}\right), 2.42\left(\mathrm{~s}, 3 \mathrm{H}, \mathrm{CH}_{3}\right), 2.10\left(\mathrm{~s}, 3 \mathrm{H}, \mathrm{CH}_{3}\right), 1.96(\mathrm{~s}, 3 \mathrm{H}$, $\left.\mathrm{CH}_{3}\right), 1.51\left(\mathrm{~s}, 3 \mathrm{H}, \mathrm{CH}_{3}\right) ;{ }^{13} \mathrm{C}-\{1 \mathrm{H}\} \mathrm{NMR}\left(75 \mathrm{MHz}, \mathrm{CD}_{2} \mathrm{Cl}_{2}, 233 \mathrm{~K}\right): \delta$ $=292.4\left(d,{ }^{2} J(C, P)=24.4 \mathrm{~Hz}, C^{1}\right), 204.7\left(d,{ }^{2} J(C, P)=13.6 \mathrm{~Hz}\right.$, $\mathrm{C}^{\prime}$ ), $154.1\left(\mathrm{~d}, J(\mathrm{C}, \mathrm{P})=19.6 \mathrm{~Hz}, \mathrm{C}_{\text {ipso }} \mathrm{C}_{6} \mathrm{H}_{4}\right), 152.6$ (broad s, $\mathrm{C}_{\text {ipso }}$ $\mathrm{C}_{6} \mathrm{H}_{4}-\mathrm{CF}_{3}$ ), 143.7 (s, CIV), 140.4 (s, CIV), 139.6 (s, C'V), 138.8 (d, 3J $\left.(C, P)=14.5 \mathrm{~Hz}, \mathrm{C}^{2}\right), 138.7\left(\mathrm{~s}, \mathrm{ClV}^{\mathrm{IV}}\right), 138.5\left(\mathrm{~s}, \mathrm{Cl}^{\mathrm{IV}}\right), 137.6\left(\mathrm{~s}, \mathrm{C}^{\mathrm{IV}}\right)$, 136.0 (s, CIV), 135.8 (s, CIV), 135.3 (s, CIV), 134.7 (s, CIV), 132.6 (s, CIV), 130.3 (q, J (C,F) = 202.5 Hz, CH Mes and $\left.C_{\text {para }} \mathrm{C}_{6} \mathrm{H}_{4}\right), 129.9$ (s, $\mathrm{C}^{7}$ and $\mathrm{CH}$ Mes), 129.6 (s, CH Mes), 129.3 (s, CH Mes and $\left.\mathrm{C}^{6}\right), 129.0$ (s, $\mathrm{C}^{11}$ and $\left.\mathrm{C}_{\text {para }} \mathrm{C}_{6} \mathrm{H}_{4}\right), 128.6$ (s, $\mathrm{C}^{10}$ and $\mathrm{C}_{\text {para }} \mathrm{C}_{6} \mathrm{H}_{4}$ ), 128.0 (broad s, $\mathrm{C}_{\text {meta }} \mathrm{C}_{6} \mathrm{H}_{4}$ ), 127.3 (s, $\mathrm{C}^{5}$ and $\mathrm{C}_{\text {para }} \mathrm{C}_{6} \mathrm{H}_{4}$ ), 126.1 (broad s, $\mathrm{C}_{\text {meta }} \mathrm{C}_{6} \mathrm{H}_{4}$ ), 125.7 (broad s, $\mathrm{C}^{9}$ and $\mathrm{CF}_{3}$ ), 123.1 (s, $\mathrm{C}_{\text {ortho }}$ $\left.\mathrm{C}_{6} \mathrm{H}_{4}\right), 121.2$ (s, Cortho $\left.\mathrm{C}_{6} \mathrm{H}_{4}\right), 121.1\left(\mathrm{~d}, J(\mathrm{C}, \mathrm{P})=10.1 \mathrm{~Hz}, \mathrm{C}_{\text {ortho }}\right.$ $\left.\mathrm{C}_{6} \mathrm{H}_{4}\right), 118.0\left(\mathrm{~s}, \mathrm{C}^{4}\right), 52.5\left(\mathrm{~s}, \mathrm{C}^{5^{\prime}}\right), 51.4\left(\mathrm{~s}, \mathrm{C}^{\prime}\right), 21.0\left(\mathrm{~s}, \mathrm{CH}_{3}\right), 20.7$ (s, $\left.\mathrm{CH}_{3}\right), 20.6\left(\mathrm{~s}, \mathrm{CH}_{3}\right), 19.0\left(\mathrm{~s}, \mathrm{CH}_{3}\right), 18.9\left(\mathrm{~s}, \mathrm{CH}_{3}\right), 18.7\left(\mathrm{~s}, \mathrm{CH}_{3}\right)$; ${ }^{31} \mathrm{P}-\left\{{ }^{1} \mathrm{H}\right\}$ NMR $\left(162 \mathrm{MHz}, \mathrm{CD}_{2} \mathrm{Cl}_{2}, 233 \mathrm{~K}\right): \delta=114.2$; Elemental Analysis Calcd (\%) for $\mathrm{C}_{57} \mathrm{H}_{48} \mathrm{Cl}_{2} \mathrm{~F}_{9} \mathrm{~N}_{2} \mathrm{O}_{3}$ PRu: C 57.87, $\mathrm{H} 4.09, \mathrm{~N}$ 2.37; Found: C 58.01, H 4.08, N 2.32.

\section{Dichloro- $\left\{N, N^{\prime}\right.$-bis[2,4,6-(trimethyl)phenyl]imidazolin-2-ylidene\}} Indenylidene)(p-chlorotriphenylphosphite) ruthenium (3d)

$66 \%$ yield, $496 \mathrm{mg} .{ }^{1} \mathrm{H}$ NMR (300 MHz, $\mathrm{CD}_{2} \mathrm{Cl}_{2}, 233 \mathrm{~K}$ ): $\delta=8.59$ $\left(d, 3 J(H, H)=7.3 \mathrm{~Hz}, 1 \mathrm{H}, \mathrm{H}^{7}\right), 7.57(\mathrm{~d}, 3 J(\mathrm{H}, \mathrm{H})=8.9 \mathrm{~Hz}, 2 \mathrm{H}$, $\left.\mathrm{C}_{6} \mathrm{H}_{4}\right), 7.48-7.38\left(\mathrm{~m}, 5 \mathrm{H}, \mathrm{H}^{9}, \mathrm{H}^{10}\right.$ and $\left.\mathrm{H}^{11}\right), 7.33-7.28(\mathrm{~m}, 3 \mathrm{H}$, $\mathrm{C}_{6} \mathrm{H}_{4}$ and $\left.\mathrm{H}^{6}\right), 7.24\left(\mathrm{t},{ }^{3} \mathrm{~J}(\mathrm{H}, \mathrm{H})=7.3 \mathrm{~Hz}, 1 \mathrm{H}, \mathrm{H}^{5}\right), 7.08(\mathrm{~s}, 1 \mathrm{H}, \mathrm{CH}$ Mes), $7.05\left(\mathrm{~d},{ }^{3} J(\mathrm{H}, \mathrm{H})=8.9 \mathrm{~Hz}, 2 \mathrm{H}, \mathrm{C}_{6} \mathrm{H}_{4}\right), 6.97\left(\mathrm{~d},{ }^{3} J(\mathrm{H}, \mathrm{H})=7.3\right.$ $\left.\mathrm{Hz}, 1 \mathrm{H}, \mathrm{H}^{4}\right), 6.94(\mathrm{~s}, 1 \mathrm{H}, \mathrm{CH}$ Mes), $6.42(\mathrm{~d}, 3 \mathrm{~J}(\mathrm{H}, \mathrm{H})=8.6 \mathrm{~Hz}, 2 \mathrm{H}$, $\left.\mathrm{C}_{6} \mathrm{H}_{4}\right), 6.24\left(\mathrm{~s}, 1 \mathrm{H}, \mathrm{CH}\right.$ Mes), $6.17\left(\mathrm{~d}, 3 \mathrm{~J}(\mathrm{H}, \mathrm{H})=8.9 \mathrm{~Hz}, 2 \mathrm{H}, \mathrm{C}_{6} \mathrm{H}_{4}\right)$, $6.15\left(\mathrm{~s}, 1 \mathrm{H}, \mathrm{CH}\right.$ Mes), $6.07\left(\mathrm{~d}, 3 \mathrm{~J}(\mathrm{H}, \mathrm{H})=9.0 \mathrm{~Hz}, 2 \mathrm{H}, \mathrm{C}_{6} \mathrm{H}_{4}\right), 5.99$ $\left(\mathrm{s}, 1 \mathrm{H}, \mathrm{H}^{2}\right)$, 4.07-3.69 (m, $4 \mathrm{H}, \mathrm{H}^{4^{\prime}}$ and $\left.\mathrm{H}^{5^{\prime}}\right), 2.73\left(\mathrm{~s}, 3 \mathrm{H}, \mathrm{CH}_{3}\right), 2.59$ (s, 3H, CH $\left.\mathrm{CH}_{3}\right), 2.43\left(\mathrm{~s}, 3 \mathrm{H}, \mathrm{CH}_{3}\right), 2.11\left(\mathrm{~s}, 3 \mathrm{H}, \mathrm{CH}_{3}\right), 1.92(\mathrm{~s}, 3 \mathrm{H}$, $\left.\mathrm{CH}_{3}\right), 1.48\left(\mathrm{~s}, 3 \mathrm{H}, \mathrm{CH}_{3}\right) ;{ }^{13} \mathrm{C}-\{1 \mathrm{H}\} \mathrm{NMR}\left(75 \mathrm{MHz}, \mathrm{CD}_{2} \mathrm{Cl}_{2}, 233 \mathrm{~K}\right): \delta$ $=292.4\left(d, 2 J(C, P)=25.0 \mathrm{~Hz}, C^{1}\right), 205.3(d, 2 J(C, P)=13.2 \mathrm{~Hz}$, $\left.C^{2}\right), 150.2\left(d,{ }^{2} J(C, P)=19.1 \mathrm{~Hz}, C_{i p s o} C_{6} H_{4}\right), 148.8\left(d,{ }^{2} J(C, P)=\right.$ $\left.13.2 \mathrm{~Hz}, \mathrm{C}_{\text {ipso }} \mathrm{C}_{6} \mathrm{H}_{4}\right), 148.7\left(\mathrm{~d},{ }^{2} \mathrm{~J}(\mathrm{C}, \mathrm{P})=22.1 \mathrm{~Hz}, \mathrm{C}_{\text {ipso }} \mathrm{C}_{6} \mathrm{H}_{4}\right)$, 142.7 (s, Clv), 140.3 (s, CIV), 139.5 (s, CIV), 138.9 (d, 3J (C,P) = 14.7 Hz, C2), 138.7 (s, CIV), 138.2 (s, CIV), 138.1 (s, CIV), 137.7 (s,

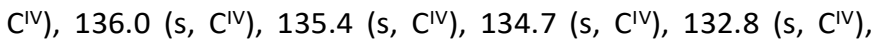

$130.3\left(\mathrm{~s}, \mathrm{C}^{9}\right), 130.1\left(\mathrm{~s}, \mathrm{C}^{5}\right), 130.0\left(\mathrm{~s}, \mathrm{C}^{7}\right), 129.9\left(\mathrm{~s}, \mathrm{C}^{10}\right), 129.6(\mathrm{~s}$, CH Mes), 129.3 (s, C11), 129.1 (s, CH Mes), 129.0 (s, CH Mes), 128.8 (s, C6), 128.7 (s, CH Mes), 128.5 (s, C C $6 \mathrm{H}_{4}$ ), 128.1 (s, C $\left.\mathrm{C}_{6} \mathrm{H}_{4}\right), 127.4\left(\mathrm{~s}, \mathrm{C} \mathrm{C}_{6} \mathrm{H}_{4}\right), 124.1\left(\mathrm{~s}, \mathrm{C} \mathrm{C}_{6} \mathrm{H}_{4}\right), 122.1\left(\mathrm{~m}, \mathrm{C} \mathrm{C}_{6} \mathrm{H}_{4}\right)$, $117.2\left(\mathrm{~s}, \mathrm{C} \mathrm{C}_{6} \mathrm{H}_{4}\right), 52.3\left(\mathrm{~s}, \mathrm{C}^{5^{\prime}}\right), 51.4\left(\mathrm{~s}, \mathrm{C}^{4^{\prime}}\right), 21.0\left(\mathrm{~s}, \mathrm{CH}_{3}\right), 20.7(\mathrm{~s}$, $\left.\mathrm{CH}_{3}\right), 20.4\left(\mathrm{~s}, \mathrm{CH}_{3}\right), 18.9\left(\mathrm{~s}, \mathrm{CH}_{3}\right), 18.7\left(\mathrm{~s}, \mathrm{CH}_{3}\right) ;{ }^{31} \mathrm{P}-\left\{{ }^{1} \mathrm{H}\right\} \mathrm{NMR}$ (162 $\mathrm{MHz}, \mathrm{CD}_{2} \mathrm{Cl}_{2}, 233 \mathrm{~K}$ ): $\delta=115.9$; Elemental Analysis Calcd (\%) for $\mathrm{C}_{54} \mathrm{H}_{48} \mathrm{Cl}_{5} \mathrm{~N}_{2} \mathrm{O}_{3} \mathrm{PRu}$ : C 59.93, H 4.47, N 2.59; Found: $\mathrm{C}$ 59.81, H 4.39, N 2.50.

Dichloro- $\left\{N, N^{\prime}\right.$-bis[2,4,6-(trimethyl)phenyl]imidazolin-2-ylidene $\}$ Indenylidene)( $p$-pentafluorosulfurtriphenylphosphite) ruthenium

(3e)

$53 \%$ yield, $480 \mathrm{mg} .{ }^{1} \mathrm{H}$ NMR (500 MHz, $\mathrm{CD}_{2} \mathrm{Cl}_{2}, 233 \mathrm{~K}$ ): $\delta=8.57$ $\left(d, 3 J(H, H)=7.5 \mathrm{~Hz}, 1 \mathrm{H}, \mathrm{H}^{7}\right), 8.05(\mathrm{~d}, 3 \mathrm{~J}(\mathrm{H}, \mathrm{H})=8.5 \mathrm{~Hz}, 2 \mathrm{H}$, $\left.\mathrm{C}_{6} \mathrm{H}_{4}\right), 7.60\left(\mathrm{~d}, 3 \mathrm{~J}(\mathrm{H}, \mathrm{H})=8.7 \mathrm{~Hz}, 2 \mathrm{H}, \mathrm{C}_{6} \mathrm{H}_{4}\right), 7.55-7.46(\mathrm{~m}, 3 \mathrm{H}$, $\mathrm{C}_{6} \mathrm{H}_{4}$ and $\left.\mathrm{H}^{11}\right), 7.38\left(\mathrm{t},{ }^{3} \mathrm{~J}(\mathrm{H}, \mathrm{H})=6.5 \mathrm{~Hz}, 2 \mathrm{H}, \mathrm{H}^{10}\right), 7.32\left(\mathrm{t},{ }^{3} \mathrm{~J}\right.$ $\left.(\mathrm{H}, \mathrm{H})=7.5 \mathrm{~Hz}, 1 \mathrm{H}, \mathrm{H}^{6}\right), 7.21\left(\mathrm{~d}, 3 \mathrm{~J}(\mathrm{H}, \mathrm{H})=6.5 \mathrm{~Hz}, 2 \mathrm{H}, \mathrm{H}^{9}\right), 7.08$ $\left(\mathrm{d}, 3 \mathrm{~J}(\mathrm{H}, \mathrm{H})=8.7 \mathrm{~Hz}, 2 \mathrm{H}, \mathrm{C}_{6} \mathrm{H}_{4}\right), 6.95(\mathrm{~s}, 1 \mathrm{H}, \mathrm{CH}$ Mes), $6.88(\mathrm{~d}, 3 \mathrm{~J}$ $\left.(\mathrm{H}, \mathrm{H})=8.5 \mathrm{~Hz}, 2 \mathrm{H}, \mathrm{C}_{6} \mathrm{H}_{4}\right), 6.66\left(\mathrm{~d}, 3 \mathrm{~J}(\mathrm{H}, \mathrm{H})=8.3 \mathrm{~Hz}, 2 \mathrm{H}, \mathrm{C}_{6} \mathrm{H}_{4}\right)$, $6.62\left(\mathrm{~d}, 3 \mathrm{~J}(\mathrm{H}, \mathrm{H})=8.3 \mathrm{~Hz}, 2 \mathrm{H}, \mathrm{C}_{6} \mathrm{H}_{4}\right), 6.40(\mathrm{~d}, 3 \mathrm{~J}(\mathrm{H}, \mathrm{H})=8.0 \mathrm{~Hz}$, $\left.2 \mathrm{H}, \mathrm{C}_{6} \mathrm{H}_{4}\right), 6.29(\mathrm{~s}, 1 \mathrm{H}, \mathrm{CH}$ Mes), 6.03 (s, 1H, CH Mes), 5.98 (s, $\left.1 \mathrm{H}, \mathrm{H}^{2}\right), 4.03-3.74\left(\mathrm{~m}, 4 \mathrm{H}, \mathrm{H}^{4^{\prime}}\right.$ and $\left.\mathrm{H}^{5^{\prime}}\right), 2.72\left(\mathrm{~s}, 3 \mathrm{H}, \mathrm{CH}_{3}\right), 2.59(\mathrm{~s}$, $\left.3 \mathrm{H}, \mathrm{CH}_{3}\right), 2.40\left(\mathrm{~s}, 3 \mathrm{H}, \mathrm{CH}_{3}\right), 2.10\left(\mathrm{~s}, 3 \mathrm{H}, \mathrm{CH}_{3}\right), 1.96\left(\mathrm{~s}, 3 \mathrm{H}, \mathrm{CH}_{3}\right)$, $1.53\left(\mathrm{~s}, 3 \mathrm{H}, \mathrm{CH}_{3}\right) ;{ }^{13} \mathrm{C}-\{1 \mathrm{H}\}$ NMR $\left(126 \mathrm{MHz}, \mathrm{CD}_{2} \mathrm{Cl}_{2}, 233 \mathrm{~K}\right): \delta=$ $292.4\left(d, 2 J(C, P)=23.4 \mathrm{~Hz}, C^{1}\right), 204.4\left(d, 2 J(C, P)=14.0 \mathrm{~Hz}, C^{2}\right)$, $153.3\left(\mathrm{~s},{ }^{2} J(\mathrm{C}, \mathrm{P})=20.3 \mathrm{~Hz}, \mathrm{C}_{\text {ipso }} \mathrm{C}_{6} \mathrm{H}_{4}\right), 152.4\left(\mathrm{~s}, \mathrm{C}^{\mathrm{IV}}\right), 151.9(\mathrm{~d}, 2 \mathrm{~J}$ $\left.(\mathrm{C}, \mathrm{P})=14.0 \mathrm{~Hz}, \mathrm{C}_{\text {ipso }} \mathrm{C}_{6} \mathrm{H}_{4}\right), 150.0\left(\mathrm{~m}, \mathrm{C} \mathrm{C}_{6} \mathrm{H}_{4}-\mathrm{SF}_{5}\right), 149.3(\mathrm{~m}, \mathrm{C}$ $\left.\mathrm{C}_{6} \mathrm{H}_{4}-\mathrm{SF}_{5}\right), 144.2$ (s, C'V), 140.4 (s, CIV), 139.7 (s, C'V), 138.9 (s, $\left.\mathrm{ClV}^{\mathrm{IV}}\right), 138.7\left(\mathrm{~s}, \mathrm{C}^{\mathrm{IV}}\right), 138.4\left(\mathrm{~d}, 3 \mathrm{~J}(\mathrm{C}, \mathrm{P})=14.0 \mathrm{~Hz}, \mathrm{C}^{2}\right), 138.0\left(\mathrm{~s}, \mathrm{C}^{\mathrm{IV}}\right)$, 137.7 (s, CIV), 136.0 (s, CIV), 135.6 (s, CIV), 135.3 (s, CIV), 134.7 (s, $\left.\mathrm{C}^{\mathrm{IV}}\right), 132.6\left(\mathrm{~s}, \mathrm{C}^{\mathrm{IV}}\right), 130.4\left(\mathrm{~m}, \mathrm{C}^{5}, \mathrm{C}^{7}\right.$ and $\left.\mathrm{C}^{9}\right), 129.9$ (s, CH Mes), $129.6\left(\mathrm{~d}, J(\mathrm{C}, \mathrm{P})=9.0 \mathrm{~Hz}, \mathrm{C} \mathrm{C}_{6} \mathrm{H}_{4}\right), 129.2$ (s, C $\left.\mathrm{C}^{6}\right), 129.0$ (s, $\left.\mathrm{C}^{11}\right)$, $128.8\left(\mathrm{~m}, \mathrm{C}^{10}\right.$ and $\left.\mathrm{C}_{6} \mathrm{H}_{4}\right), 127.6$ (s, $\left.\mathrm{Cl}^{\mathrm{IV}}\right), 127.3$ (s, $\left.\mathrm{C}^{9}\right), 126.9$ (s, $\left.\mathrm{C} \mathrm{C}_{6} \mathrm{H}_{4}\right), 126.5$ (s, $\left.\mathrm{C} \mathrm{C}_{6} \mathrm{H}_{4}\right), 124.2$ (s, Clv), 122.7 (s, C C $\left.6 \mathrm{H}_{4}\right), 120.9$ (s, $\left.\mathrm{C} \mathrm{C}_{6} \mathrm{H}_{4}\right), 120.8\left(\mathrm{~s}, \mathrm{C} \mathrm{C}_{6} \mathrm{H}_{4}\right), 118.5\left(\mathrm{~s}, \mathrm{C}^{4}\right), 52.6\left(\mathrm{~s}, \mathrm{C}^{5}\right), 51.4(\mathrm{~s}$, $\left.\mathrm{C}^{4^{\prime}}\right), 21.0\left(\mathrm{~s}, \mathrm{CH}_{3}\right), 20.7\left(\mathrm{~s}, \mathrm{CH}_{3}\right), 20.7\left(\mathrm{~s}, \mathrm{CH}_{3}\right), 19.0\left(\mathrm{~s}, \mathrm{CH}_{3}\right), 18.9$ (s, $\left.\mathrm{CH}_{3}\right), 18.7$ (s, $\left.\mathrm{CH}_{3}\right) ;{ }^{31} \mathrm{P}-\left\{{ }^{1} \mathrm{H}\right\}$ NMR (162 MHz, $\left.\mathrm{CD}_{2} \mathrm{Cl}_{2}, 233 \mathrm{~K}\right): \delta$ $=114.4$; Elemental Analysis Calcd (\%) for $\mathrm{C}_{54} \mathrm{H}_{48} \mathrm{Cl}_{2} \mathrm{~F}_{15} \mathrm{~N}_{2} \mathrm{O}_{3}$ PRuS 3 : C 47.79, H 3.57, N 2.06; Found: C 47.62, H 3.48, N 2.08.

Dichloro- $\left\{N, N^{\prime}\right.$-bis $[2,4,6$-(trimethyl)phenyl]imidazolin-2-ylidene $\}$ Indenylidene)(p-cyanotriphenylphosphite) ruthenium (3f) $90 \%$ yield, $633 \mathrm{mg} .{ }^{1} \mathrm{H}$ NMR (500 MHz, $\mathrm{CD}_{2} \mathrm{Cl}_{2}, 233 \mathrm{~K}$ ): $\delta=8.58$ $\left.(d, 3)(H, H)=7.4 \mathrm{~Hz}, 1 \mathrm{H}, \mathrm{H}^{7}\right), 7.97(\mathrm{~d}, 3 \mathrm{~J}(\mathrm{H}, \mathrm{H})=8.6 \mathrm{~Hz}, 2 \mathrm{H}$, $\left.\mathrm{C}_{6} \mathrm{H}_{4}\right), 7.59\left(\mathrm{~d}, 3 \mathrm{~J}(\mathrm{H}, \mathrm{H})=8.0 \mathrm{~Hz}, 2 \mathrm{H}, \mathrm{H}^{9}\right), 7.52(3 \mathrm{~J}(\mathrm{H}, \mathrm{H})=7.4 \mathrm{~Hz}$, $\left.1 \mathrm{H}, \mathrm{H}^{6}\right), 7.44\left(\mathrm{~m}, 4 \mathrm{H}, \mathrm{C}_{6} \mathrm{H}_{4}\right.$ and $\left.\mathrm{H}^{10}\right), 7.31\left(\mathrm{~m}, 3 \mathrm{H}, \mathrm{C}_{6} \mathrm{H}_{4}\right.$ and $\left.\mathrm{H}^{11}\right)$, $7.27\left(\mathrm{t},{ }^{3} \mathrm{~J}(\mathrm{H}, \mathrm{H})=7.4,1 \mathrm{H}, \mathrm{H}^{5}\right), 7.10(\mathrm{~s}, 1 \mathrm{H}, \mathrm{CH}$ Mes $), 6.97\left(\mathrm{~d},{ }^{3} \mathrm{~J}\right.$ $\left.(\mathrm{H}, \mathrm{H})=7.4 \mathrm{~Hz}, 1 \mathrm{H}, \mathrm{H}^{4}\right), 6.93(\mathrm{~s}, 1 \mathrm{H}, \mathrm{CH}$ Mes $), 6.54(\mathrm{~d}, 3 \mathrm{~J}(\mathrm{H}, \mathrm{H})=$ $\left.8.6 \mathrm{~Hz}, 2 \mathrm{H}, \mathrm{C}_{6} \mathrm{H}_{4}\right), 6.49\left(\mathrm{~d}, 3 \mathrm{~J}(\mathrm{H}, \mathrm{H})=8.2 \mathrm{~Hz}, 2 \mathrm{H}, \mathrm{C}_{6} \mathrm{H}_{4}\right), 6.31(\mathrm{~d}, 3 \mathrm{~J}$ $(\mathrm{H}, \mathrm{H})=8.2 \mathrm{~Hz}, 3 \mathrm{H}, \mathrm{C}_{6} \mathrm{H}_{4}$ and $\left.\mathrm{H}^{2}\right), 6.12(\mathrm{~s}, 1 \mathrm{H}, \mathrm{CH}$ Mes), $5.92(\mathrm{~s}$, $1 \mathrm{H}, \mathrm{CH}$ Mes), 4.06-3.73 (m, $4 \mathrm{H}, \mathrm{H}^{4^{\prime}}$ and $\left.\mathrm{H}^{\mathrm{j}^{\prime}}\right), 2.72\left(\mathrm{~s}, 3 \mathrm{H}, \mathrm{CH}_{3}\right)$, $2.57\left(\mathrm{~s}, 3 \mathrm{H}, \mathrm{CH}_{3}\right), 2.47\left(\mathrm{~s}, 3 \mathrm{H}, \mathrm{CH}_{3}\right), 2.10\left(\mathrm{~s}, 3 \mathrm{H}, \mathrm{CH}_{3}\right), 1.92(\mathrm{~s}$, $\left.3 \mathrm{H}, \mathrm{CH}_{3}\right), 1.47\left(\mathrm{~s}, 3 \mathrm{H}, \mathrm{CH}_{3}\right) ;{ }^{13} \mathrm{C}-\{1 \mathrm{H}\}$ NMR $\left(126 \mathrm{MHz}, \mathrm{CD}_{2} \mathrm{Cl}_{2}\right.$, 233K): $\delta=292.2\left(d,{ }^{2} J(C, P)=25.6 \mathrm{~Hz}, C^{1}\right), 204.4\left(d,{ }^{2} J(C, P)=\right.$ $\left.13.8 \mathrm{~Hz}, \mathrm{C}^{\prime}\right), 154.5\left(\mathrm{~d}, 2 \mathrm{~J}(\mathrm{C}, \mathrm{P})=20.0 \mathrm{~Hz}, \mathrm{C} \mathrm{C}_{6} \mathrm{H}_{4}\right), 153.3(\mathrm{~d}, 2 \mathrm{~J}$ $\left.(C, P)=7.7 \mathrm{~Hz}, C_{6} \mathrm{C}_{4}\right), 153.0\left(\mathrm{~d}, 2 J(C, P)=13.9 \mathrm{~Hz}, \mathrm{C} \mathrm{C}_{6} \mathrm{H}_{4}\right)$, 143.6 (s, ClV), 140.2 (s, CIV), 139.7 (s, CH Mes), 139.4 (d, 3J (C,P) 
= $\left.15.4 \mathrm{~Hz}, \mathrm{C}^{2}\right), 138.9$ (s, CIV), 137.9 (s, CIV), $137.8\left(\mathrm{~s}, \mathrm{C}^{\mathrm{IV}}\right), 135.8$ (s, CIV), 135.5 (s, CIV), 135.3 (s, CIV), 135.1 (s, $\mathrm{C} \mathrm{C}_{6} \mathrm{H}_{4}$ ), 134.6 (s, CIV), 134.0 (s, C'V), 133.8 (s, CIV), 133.6 (s, CIV), 133.1 (s, $\mathrm{C} \mathrm{C}_{6} \mathrm{H}_{4}$ ), 132.9 (s, C ${ }^{10}$ ), 132.3 (s, C'V), 130.7 (s, C5), 130.3 (s, CH Mes and $\mathrm{C}^{7}$ ), 130.2 (s, CH Mes), 129.5 (m, CH Mes, $\mathrm{C}^{11}$ and $\mathrm{C}^{6}$ ), 129.3 (s, $\left.\mathrm{C}^{2}\right), 128.9\left(\mathrm{~s}, \mathrm{C} \mathrm{C}_{6} \mathrm{H}_{4}\right), 127.4\left(\mathrm{~s}, \mathrm{C} \mathrm{C}_{6} \mathrm{H}_{4}\right), 127.4\left(\mathrm{~s}, \mathrm{C} \mathrm{C}_{6} \mathrm{H}_{4}\right), 123.7$ (s, $\left.\mathrm{C} \mathrm{C}_{6} \mathrm{H}_{4}\right), 121.7$ (s, $\left.\mathrm{C} \mathrm{C}_{6} \mathrm{H}_{4}\right), 121.5$ (s, $\left.\mathrm{C}^{9}\right), 118.5$ (s, Clv), 118.0 $\left(\mathrm{s}, J(\mathrm{C}, \mathrm{P})=10.0 \mathrm{~Hz} \mathrm{C} \mathrm{C} \mathrm{H}_{4}\right), 117.7\left(\mathrm{~s}, \mathrm{C}^{4}\right), 109.6(\mathrm{~s}, \mathrm{CN}), 108.8(\mathrm{~s}$, $\mathrm{CN}), 108.3(\mathrm{~s}, \mathrm{CN}), 52.3\left(\mathrm{~s}, \mathrm{C}^{\prime}\right), 51.5\left(\mathrm{~s}, \mathrm{C}^{\prime}\right), 20.9\left(\mathrm{~s}, \mathrm{CH}_{3}\right), 20.7$ (s, $\left.\mathrm{CH}_{3}\right), 20.3\left(\mathrm{~s}, \mathrm{CH}_{3}\right), 18.9\left(\mathrm{~s}, \mathrm{CH}_{3}\right) ;{ }^{31} \mathrm{P}-\left\{{ }^{1} \mathrm{H}\right\} \mathrm{NMR}(121 \mathrm{MHz}$, $\left.\mathrm{CD}_{2} \mathrm{Cl}_{2}, 233 \mathrm{~K}\right): \delta=115.3$; Elemental Analysis Calcd (\%) for $\mathrm{C}_{57} \mathrm{H}_{48} \mathrm{Cl}_{2} \mathrm{~N}_{5} \mathrm{O}_{3}$ PRu: $\mathrm{C}$ 64.96, H 4.59, N 6.64; Found: C 64.72, H 4.35, N 6.53.

\section{Computational Details}

All calculations were performed with the Gaussian09 package Gaussian 09, Revision A.1, ${ }^{35}$ at the BP86 GGA level ${ }^{36}$ using the SDD ECP on $\mathrm{Ru}^{37}$ and the split-valence plus one polarization function SVP basis set on all main group atoms during geometry optimizations. ${ }^{38}$ The reported energies have been obtained through single point energy calculations with $\mathrm{M06}^{39}$ via single point calculations at the BP86 level using the triple- $\zeta$ plus one polarization function TZVP basis set for main group atoms. Solvent effects, toluene and nitromethane, were included with the PCM model. 40 The electrophilicity of the complexes is evaluated as the Parr electrophilicity index shown in eq 1,41

$$
\omega=\frac{\mu^{2}}{2 \eta},
$$

where $\mu$ and $\eta$ are the chemical potential and the molecular hardness, respectively. In the framework of DFT, $42 \mu$ and $n$ for a $\mathrm{N}$-electron system with total electronic energy $\mathrm{E}$ are defined as the first and second derivatives of the energy with respect to $\mathrm{N}$ at a fixed external potential. ${ }^{43}$ In numerical applications, $\mu$ and $\eta$ are calculated with the finite difference formulas of eq 2 , which are based on Koopmans' approximation, ${ }^{44}$

$$
\mu \cong \frac{1}{2}\left(\varepsilon_{L}+\varepsilon_{H}\right) \quad \eta \cong \frac{1}{2}\left(\varepsilon_{L}-\varepsilon_{H}\right),
$$

where $\varepsilon_{H}$ and $\varepsilon_{L}$ are the energies of the highest occupied molecular orbital (HOMO) and the lowest unoccupied molecular orbital (LUMO), respectively. Over the last years, conceptual DFT has been used to explain the reactivity pattern, and in particular the regioselectivity in chemical reactions. ${ }^{45}$

\section{Conflicts of interest}

There are no conflicts to declare.

\section{Acknowledgements}

The authors gratefully acknowledge the Royal Society (University Research Fellowship to CSJC), the EC (CP-FP 211468-2 EUMET and CIG09-GA-2011-293900) and the Spanish
Ministry of Economy and Competitiveness (CTQ2014-59832JIN to AP) for funding.

\section{Notes and references}

1 (a) K. Grela, Olefin Metathesis: Theory and Practice, Wiley, 2014; (b) S. P. Nolan, N-Heterocyclic Carbenes: Effective Tools for Organometallic Synthesis, Wiley, 2014; (c) R. H. Grubbs, A. G. Wenzel, D. J. O'Leary and E. Khosravi Handbook of Metathesis, Wiley, 2015.

2 (a) R. H. Grubbs, S. J. Miller and G. C. Fu, Acc. Chem. Res. 1995, 28, 446-452; (b) A. K. Ghosh and Y. Wang, J. Am. Chem. Soc. 2000, 122, 11027-11028; (c) H. Tang, N. Yusuff and J. L. Wood, Org. Lett. 2001, 3, 1563-1566; (d) K. Biswas, H. Lin, J. T. Njardarson, M. D. Chappell, T.-C. Chou, Y. Guan, W. P. Tong, L. He, S. B. Horwitz and S. J. Danishefsky, J. Am. Chem. Soc. 2002, 124, 9825-9832; (e) S. Jian and S. S. C., Angew. Chem. Int. Ed. 2002, 41, 1381-1383; (f) B. M. Trost and V. S. C. Yeh, Org. Lett. 2002, 4, 3513-3516; (g) J. Cossy, S. Arseniyadis and C. Meyer, Metathesis in Natural Product Synthesis, Wiley, 2010; (h) D. Hughes, P. Wheeler and D. Ene, Org. Process Res. Dev. 2017, 21, 1938-1962.

3 (a) G. Ping-Hua, F. Wei, H. W. A., H. Eberhardt, C. Charles, A. R. D. and B. U. H. F., Angew. Chem. Int. Ed. 2000, 39, 36073610; (b) N. G. Pschirer, W. Fu, R. D. Adams and U. H. F. Bunz, Chem. Commun. 2000, 87-88; (c) B. Mayr, G. Holzl, K. Eder, M. R. Buchmeiser and C. G. Huber, Anal. Chem. 2002, 74, 6080-6087.

4 (a) S. Guidone, O. Songis, F. Nahra and C. S. J. Cazin, ACS Catalysis 2015, 5, 2697-2701; (b) Z. J. Wang, W. R. Jackson and A. J. Robinson, Green Chem. 2015, 17, 3407-3414.

5 (a) T. M. Trnka and R. H. Grubbs, Acc. Chem. Res. 2001, 34, 18-29; (b) G. Occhipinti, F. R. Hansen, K. W. Törnroos and V. R. Jensen, J. Am. Chem. Soc. 2013, 135, 3331-3334; (c) M. J. Koh, R. K. M. Khan, S. Torker, M. Yu, M. S. Mikus and A. H. Hoveyda, Nature 2015, 517, 181.

6 (a) G. C. Vougioukalakis and R. H. Grubbs, Chem. Rev. 2010, 110, 1746-1787; (b) O. M. Ogba, N. C. Warner, D. J. O'Leary and R. H. Grubbs, Chem. Soc. Rev. 2018, 47, 4510-4544.

7 P. Schwab, M. B. France, J. W. Ziller and R. H. Grubbs, Angew. Chem. Int. Ed. 1995, 34, 2039-2041.

8 (a) T. Weskamp, W. C. Schattenmann, M. Spiegler and W. A. Herrmann, Angew. Chem. Int. Ed. 1998, 37, 2490-2493; (b) J. Huang, E. D. Stevens, J. L. Petersen, S. P. Nolan, J. Am. Chem. Soc. 1999, 121, 2674-2678.; (c) J. Huang, H.-J. Schanz, E. D. Stevens and S. P. Nolan, Organometallics 1999, 18, 53755380; (d) M. Scholl, T. M. Trnka, J. P. Morgan and R. H. Grubbs, Tetrahedron Lett. 1999, 40, 2247-2250.

9 (a) J. S. Kingsbury, J. P. A. Harrity, P. J. Bonitatebus and A. H. Hoveyda, J. Am. Chem. Soc. 1999, 121, 791-799; (b) S. B. Garber, J. S. Kingsbury, B. L. Gray and A. H. Hoveyda, J. Am. Chem. Soc. 2000, 122, 8168-8179; (c) S. Gessler, S. Randl and S. Blechert, Tetrahedron Lett. 2000, 41, 9973-9976.

10 (a) L. Jafarpour, H.-J. Schanz, E. D. Stevens and S. P. Nolan, Organometallics 1999, 18, 5416-5419; (b) A. Fürstner, J. Grabowski and C. W. Lehmann, J. Org. Chem 1999, 64, 82758280; (c) K. J. Harlow, A. F. Hill and J. D. E. T. Wilton-Ely, J. Chem. Soc., Dalton Trans. 1999, 285-292; (d) F. Boeda, H. Clavier and S. P. Nolan, Chem. Commun. 2008, 2726-2740; (e) C. A. Urbina-Blanco, A. Poater, T. Lebl, S. Manzini, A. M. Z. Slawin, L. Cavallo and S. P. Nolan, J. Am. Chem. Soc. 2013, 135, 7073-7079. (f) C. A. Urbina-Blanco, S. Guidone, S. P. Nolan, C. S. J. Cazin in Ruthenium-indenylidene and other alkylidene containing olefin metathesis catalysts, John Wiley \& Sons, Inc., 2014, pp 417-436.;

11 (a) H. Clavier, J. L. Petersen and S. P. Nolan, J. Organomet. Chem. 2006, 691, 5444-5447; (b) H. Clavier and S. P. Nolan, 
NATO Sci. Ser., II 2007, 243, 29-37; (c) S. Monsaert, E. De Canck, R. Drozdzak, P. Van Der Voort, F. Verpoort, J. C. Martins and P. M. S. Hendrickx, Eur. J. Org. Chem. 2009, 655665; (d) C. A. Urbina-Blanco, A. Leitgeb, C. Slugovc, X Bantreil, H. Clavier, A. M. Z. Slawin and S. P. Nolan, Chem Eur. J. 2011, 17, 5045-5053; (e) C. A. Urbina-Blanco, S. Manzini, J. P. Gomes, A. Doppiu and S. P. Nolan, Chem. Commun. 2011, 47, 5022-5024; (f) S. Manzini, C. A. Urbina Blanco, A. M. Z. Slawin and S. P. Nolan, Organometallics 2012, 31, 6514-6517.

12 (a) A. Poater, L. Falivene, C. A. Urbina-Blanco, S. Manzini, S. P. Nolan and L. Cavallo, Dalton Trans. 2013, 42, 7433-7439; (b) S. Manzini, A. Poater, D. J. Nelson, L. Cavallo, A. M. Z. Slawin and S. P. Nolan, Angew. Chem. Int. Ed. 2014, 53, 89958999; (c) G. A. Bailey and D. E. Fogg, J. Am. Chem. Soc. 2015 137, 7318-7321; (d) S. Manzini, C. A. Urbina Blanco, D. J. Nelson, A. Poater, T. Lebl, S. Meiries, A. M. Z. Slawin, L. Falivene, L. Cavallo and S. P. Nolan, J. Organomet. Chem. 2015, 780, 43-48; (e) K. Endo and R. H. Grubbs, Dalton Trans. 2016, 45, 3627-3634; (f) G. A. Bailey, J. A. M. Lummiss, M Foscato, G. Occhipinti, R. McDonald, V. R. Jensen and D. E. Fogg, J. Am. Chem. Soc. 2017, 139, 16446-16449; $(g)$ P. S. Engl, C. B. Santiago, C. P. Gordon, W.-C. Liao, A. Fedorov, C. Copéret, M. S. Sigman and A. Togni, J. Am. Chem. Soc. 2017, 139, 13117-13125; (h) A. G. Santos, G. A. Bailey, E. N. dos Santos and D. E. Fogg, ACS Catalysis 2017, 7, 3181-3189; (i) C. K. Chu, T.-P. Lin, H. Shao, A. L. Liberman-Martin, P. Liu and R. H. Grubbs, J. Am. Chem. Soc. 2018, 140, 5634-5643.

13 R. B. Bedford and S. L. Welch, Chem. Commun. 2001, 129130.

14 R. B. Bedford, C. S. J. Cazin and S. L. Hazelwood Angew. Chem. 2002, 114, 4294-4296.

15 C.-Y. Ho and T. F. Jamison, Angew. Chem. Int. Ed. 2007, 46, 782-785.

16 (a) X. Bantreil, T. E. Schmid, R. A. M. Randall, A. M. Z. Slawin and C. S. J. Cazin, Chem. Commun. 2010, 46, 7115-7117; (b) T. E. Schmid, X. Bantreil, C. A. Citadelle, A. M. Z. Slawin and C. S. J. Cazin, Chem. Commun. 2011, 47, 7060-7062; (c) X. Bantreil, A. Poater, C. A. Urbina-Blanco, Y. D. Bidal, L. Falivene, R. A. M. Randall, L. Cavallo, A. M. Z. Slawin and C. S J. Cazin, Organometallics 2012, 31, 7415-7426; (d) O. Songis, A. M. Z. Slawin and C. S. J. Cazin, Chem. Commun. 2012, 48, 1266-1268; (e) L. Falivene, A. Poater, C. S. J. Cazin, C. Slugove and L. Cavallo, Dalton Trans. 2013, 42, 7312-7317; (f) C. A. Urbina-Blanco, X. Bantreil, J. Wappel, T. E. Schmid, A. M. Z. Slawin, C. Slugovc and C. S. J. Cazin, Organometallics 2013 32, 6240-6247; ( $g$ ) A. Leitgeb, J. Wappel, C. A. Urbina-Blanco, S. Strasser, C. Wappl, C. S. J. Cazin and C. Slugovc, Monatsh. Chem. 2014, 145, 1513-1517; (h) S. Guidone, F. Nahra, A. M. Z. Slawin and C. S. J. Cazin, Beilstein J. Org. Chem. 2015, 11 1520-1527; (i) S. Guidone, O. Songis, L. Falivene, F. Nahra, A. M. Z. Slawin, H. Jacobsen, L. Cavallo and C. S. J. Cazin, ACS Catal. 2015, 5, 3932-3939; (j) S. Guidone, O. Songis, F. Nahra and C. S. J. Cazin, ACS Catal. 2015, 5, 2697-2701; (k) X. Bantreil and C. S. J. Cazin, Monatsh. Chem., 2015, 146, 10431052.

17 (a) J. A. Love, M. S. Sanford, M. W. Day and R. H. Grubbs, J. Am. Chem. Soc. 2003, 125, 10103-10109; (b) J. Broggi, C. A. Urbina-Blanco, H. Clavier, A. Leitgeb, C. Slugovc, A. M. Z. Slawin and S. P. Nolan, Chem. Eur. J. 2010, 16, 9215-9225.

18 (a) C. A. Tolman, W. C. Seidel and L. W. Gosser, J. Am. Chem. Soc. 1974, 96, 53-60; (b) C. A. Tolman, Chem. Rev. 1977, 77 313-348.

19 (a) C. Hansch, A. Leo and R. W. Taft, Chem. Rev. 1991, 91, 165-195; (b) R. C. Seiceira, C. M. Higa, A. G. Barreto and J. F. Cajaiba da Silva, Thermochim. Acta 2005, 428, 101-104.

20 J. Hernández, F. M. Goycoolea, D. Zepeda-Rivera, J. JuárezOnofre, K. Martínez, J. Lizardi, M. Salas-Reyes, B. Gordillo, C.
Velázquez-Contreras, O. García-Barradas, S. Cruz-Sánchez and Z. Domínguez, Tetrahedron 2006, 62, 2520-2528.

21 (a) C. Adlhart, C. Hinderling, H. Baumann and P. Chen, J. Am. Chem. Soc. 2000, 122, 8204-8214; (b) M. S. Sanford, M. Ulman and R. H. Grubbs, J. Am. Chem. Soc. 2001, 123, 749750.

22 S. A. Serron and S. P. Nolan, Organometallics 1995, 14, 46114616.

23 CCDC1023424-1023433 contain the supplementary crystallographic data (complexes $\mathbf{2 b}$-f and $\mathbf{3 b}$-f). These data can be obtained free of charge from the Cambridge Crystallographic Data Centre via www.ccdc.cam.ac.uk/data request/cif;

$24 \% V_{\text {Bur }}$ calculated from the web application SambVca https://www.molnac.unisa.it/OM/sambvca.php; see ESI for details.

25 (a) H. Jacobsen, A. Correa, A. Poater, C. Costabile and L. Cavallo, Coord. Chem. Rev. 2009, 253, 687-703; (b) A. Poater, B. Cosenza, A. Correa, S. Giudice, F. Ragone, V. Scarano and L. Cavallo, Eur. J. Inorg. Chem. 2009, 2009, 1759-1766; (c) R. Credendino, A. Poater, F. Ragone and L. Cavallo, Catal. Sci. Technol. 2011, 1, 1287-1297.

26 For a report showing NHC adapting bulkiness, see: T. E. Schmid, D. C. Jones, O. Diebolt, M. R. L. Furst, A. M. Z. Slawin and C. S. J. Cazin Dalton Trans. 2013, 42, 7345-7353.

27 D. J. Nelson, S. Manzini, C. A. Urbina-Blanco and S. P. Nolan, Chem. Commun. 2014, 50, 10355-10375.

28 (a) M. Scholl, S. Ding, C. W. Lee and R. H. Grubbs, Org. Lett. 1999, 1, 953-956; (b) J. M. Berlin, K. Campbell, T. Ritter, T. W. Funk, A. Chlenov and R. H. Grubbs, Org. Lett. 2007, 9, 13391342; (c) I. C. Stewart, T. Ung, A. A. Pletnev, J. M. Berlin, R. H. Grubbs and Y. Schrodi, Org. Lett. 2007, 9, 1589-1592.

29 E. Ivry, A. Frenklah, Y. Ginzburg, E. Levin, I. Goldberg, S. Kozuch, N. G. Lemcoff and E. Tzur, Organometallics 2018, 37, 176-181.

30 (a) W.-Z. Zhang, R. He and R. Zhang, Eur. J. Inorg. Chem. 2007, 2007, 5345-5352; (b) L. Vieille-Petit, H. Clavier, A. Linden, S. Blumentritt, S. P. Nolan and R. Dorta, Organometallics 2010, 29, 775-788; (c) R. Schowner, I. Elser, F. Toth, E. Robe, W. Frey and M. R. Buchmeiser, Chem. Eur. J. 2018, 24, 13336-13347.

31 Addition of ethylene has been proved sometimes necessary to perform the reaction with such terminal alkynes: $(a) \mathrm{M}$. Mori, N. Sakakibara and A. Kinoshita, J. Org. Chem. 1998, 63, 6082-6083; (b) G. C. Lloyd-Jones, R. G. Margue and J. G. de Vries, Angew. Chem. Int. Ed. 2005, 44, 7442-7447; (c) A. G. D. Grotevendt, J. A. M. Lummiss, M. L. Mastronardi and D. E. Fogg, J. Am. Chem. Soc. 2011, 133, 15918-15921.

32 Phosphite 1a is commercially available. Procedures for the synthesis of $\mathbf{1 b}-\mathbf{d}$ and characterisation were previously reported. See ESI for details.

33 Complex 2a has been described in $(a)$ E. Hodson, S. J. Simpson, Polyhedron 2004, 23, 2695-2707; (b) S. A. Serron, S. P. Nolan, Organometallics 1995, 14, 4611-4616.

34 Synthesis and characterisation of 3a have been reported in ref. $16 \mathrm{c}$.

35 Gaussian 09, Revision A.1, M. J. Frisch, G. W. Trucks, H. B. Schlegel, G. E.Scuseria, M. A. Robb, J. R. Cheeseman, G. Scalmani, V. Barone, B. Mennucci, G. A. Petersson, H. Nakatsuji, M. Caricato, X. Li, H. P. Hratchian, A. F. Izmaylov, J. Bloino, G. Zheng, J. L. Sonnenberg, M. Hada, M. Ehara, K. Toyota, R. Fukuda, J. Hasegawa, M. Ishida, T. Nakajima, Y. Honda, O. Kitao, H. Nakai, T. Vreven, J. A. Montgomery, Jr., J. E. Peralta, F. Ogliaro, M. Bearpark, J. J. Heyd, E. Brothers, K. N. Kudin, V. N. Staroverov, R. Kobayashi, J. Normand, K. Raghavachari, A. Rendell, J. C. Burant, S. S. Iyengar, J. Tomasi, M. Cossi, N. Rega, J. M. Millam, M. Klene, J. E. Knox, J. B. Cross, V. Bakken, C. Adamo, J. Jaramillo, R. Gomperts, R. E. 
Stratmann, O. Yazyev, A. J. Austin, R. Cammi, C. Pomelli, J. W. Ochterski, R. L. Martin, K. Morokuma, V. G. Zakrzewski, G. A. Voth, P. Salvador, J. J. Dannenberg, S. Dapprich, A. D. Daniels, Ö. Farkas, J. B. Foresman, J. V. Ortiz, J. Cioslowski, and D. J. Fox, Gaussian, Inc., Wallingford CT, 2009.

36 (a) J. P. Perdew, Phys. Rev. B 1986, 33, 8822-8824; (b) J. P. Perdew, Phys. Rev. B 1986, 34, 7406-7406; (c) A. D. Becke, Phys. Rev. A 1988, 38, 3098-3100.

37 (a) U. Häussermann, M. Dolg, H. Stoll, H. Preuss, P. Schwerdtfeger and R. M. Pitzer, Mol. Phys. 1993, 78, 12111224; $(b)$ W. Küchle, M. Dolg, H. Stoll and H. Preuss, J. Chem. Phys. 1994, 100, 7535-7542; (c) T. Leininger, A. Nicklass, H. Stoll, M. Dolg and P. Schwerdtfeger, J. Chem. Phys. 1996, 105, 1052-1059.

38 A. Schäfer, H. Horn and R. Ahlrichs, J. Chem. Phys. 1992, 97, 2571-2577.

39 Y. Zhao and D. G. Truhlar, Theor. Chem. Acc. 2008, 120, 215241.

40 (a) J. Tomasi and M. Persico, Chem. Rev. 1994, 94, $2027-$ 2094; (b) V. Barone and M. Cossi, J. Phys. Chem. A 1998, 102 1995-2001.

41 R. G. Parr, L. v. Szentpály and S. Liu, J. Am. Chem. Soc. 1999, 121, 1922-1924.

42 P. Geerlings, F. De Proft and W. Langenaeker, Chem. Rev. 2003, 103, 1793-1874.

43 (a) R. G. Parr, W. Yang, Density Functional Theory of Atoms and Molecules, Oxford University Press: New York, 1989; (b) R. G. Parr, R. A. Donnelly, M. Levy and W. E. Palke, J. Chem. Phys. 1978, 68, 3801-3807; (c) R. G. Parr and R. G. Pearson, J. Am. Chem. Soc. 1983, 105, 7512-7516.

44 T. Koopmans, Physica 1934, 1, 104-113.

45 (a) P. W. Ayers, R. G. Parr. J. Am. Chem. Soc. 2000, 122, 20102018; (b) A. Poater, M. Duran, P. Jaque, A. Toro-Labbé, M. Solà, J. Phys. Chem. B 2006, 110, 6526-6536; (c) A. Poater, F. Ragone, A. Correa, L. Cavallo, J. Am. Chem. Soc. 2009, 131, 9000-9006. 